\author{
UNIVERSIDADE DE SÃO PAULO \\ INSTITUTO DE QUÍMICA \\ Programa de Pós-Graduação em Ciências Biológicas (Bioquímica)
}

NICOLE QUESADA TORELLI

Sinalização Retrógrada RTG-Dependente Controla a Atividade Mitocondrial e Resistência a Estresse em Saccharomyces cerevisiae

Versão corrigida da Dissertação defendida

São Paulo

Data do Depósito na SPG:

$01 / 10 / 2014$ 

NICOLE QUESADA TORELLI

\section{Sinalização Retrógrada RTG-Dependente Controla a Atividade Mitocondrial e Resistência a Estresse em Saccharomyces cerevisiae}

Dissertação apresentada ao Instituto de Química da Universidade de São Paulo para obtenção do Título de Mestre em Ciências (Bioquímica).

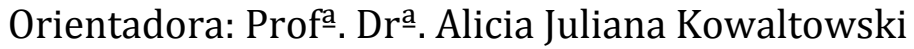

Co-orientadora: Profa $\stackrel{\text { a }}{\text { Dra }}$. Fernanda Marques da Cunha

São Paulo

2014 


\section{Ficha Catalográfica}

Elaborada pela Divisão de Biblioteca e

Documentação do Conjunto das Químicas da USP.

Torelli, Nicole Quesada

T678s Sinalização retrógrada RTG-dependente controla a atividade mitocondrial e resistência a estresse em Saccharomyces cerevisiae / Nicole Quesada Torelli. -- São Paulo, 2014. $58 \mathrm{p}$.

Dissertação (mestrado) - Instituto de Química da Universidade de São Paulo. Departamento de Bioquímica.

Orientador: Kowaltowski, Alicia Juliana

Co-orientador: Cunha, Fernanda Marques da

1. Bioquímica 2. 3. Mitocondrias I. T. II. Kowaltowski, Alicia Juliana, orientador III. Cunha, Fernanda Marques da, Coorientador 


Ao meu amado noivo, Vítor, aos meus queridos pais, Elaine e Darwin, e ao meu adorado irmão, Thiago, por todo o apoio, carinho e paciência sem os quais este trabalho não seria possível. 



\section{AGRADECIMENTOS}

À minha orientadora, Alicia Kowaltowski, e à minha co-orientadora, Fernanda Cunha, minha eterna gratidão pelo carinho, paciência e excelente orientação. Graças a vocês o aprendizado que tive nos últimos anos foi não só muito valioso como muito prazeroso. Agradeço a Alicia também por todos os estímulos gastronômicos e a Fernanda por todas as vezes em que ela deu duro para me ajudar com meus experimentos.

Ao professor José Ribamar Ferreira Júnior, sem o qual este projeto provavelmente não teria existido.

A Camille Caldeira, pelo apoio técnico, pela amizade e pela paciência de me mostrar tantas vezes que o reagente que eu procurava estava bem debaixo do meu nariz.

A todos os membros do laboratório, passados e presentes: Ariel Cardoso, Bruno Chausse, Bruno Queliconi, Felipe Macedo, Ignacio Amigo, Julia Peloggia, Luis Alberto Luévano, Marcel Lara, Maria Fernanda Forni, Pâmela Kakimoto, Phillipe Pessoa, Sérgio de Menezes, Talita Romanatto e Wilson Garcia. Muitíssimo obrigada pelas discussões científicas, pelos protocolos experimentais e também pela amizade, pelas risadas, pelas músicas de estilo duvidoso cantadas em conjunto no laboratório, pelas Coca-colas compartilhadas em dias em que o experimento não funcionava, enfim, por fazer do laboratório uma família da qual sentirei muita saudade.

A Doris Araújo e Edson Gomes, pela alegria contagiosa e pelo apoio sem o qual nenhum trabalho no laboratório seria possível.

Aos colegas de outros laboratórios que me estenderam a mão quando eu precisei de ajuda, Fernando Gomes, Luiza Grecco e Marques, Edlaine Linares, Maíra Nagal, Artur Guazzelli, Carlos Henrique Gomes e aos seus orientadores e supervisores. Em especial a todos os membros do Laboratório de Genética Mitocondrial e à professora Nadja Christina de Souza-Pinto. 
Aos membros da minha banca de qualificação, Bayardo Baptista Torres, Frederico José Gueiros Filho e Maria Julia Manso Alves, pelos valiosos comentários que auxiliaram no amadurecimento deste trabalho.

Ao professor da Université de Lyon, Hugo Aguilaniu, pelas discussões em congressos, pelo convite à França e pelos conselhos que me ajudaram a definir o próximo passo da minha carreira.

À equipe da Sessão de Pós-Graduação do Instituto de Química, da Secretaria do Departamento de Bioquímica e da Secretaria da Sociedade Brasileira de Bioquímica e Biologia Molecular.

Ao Conselho Nacional de Desenvolvimento Científico e Tecnológico.

Aos preciosos amigos Camila Bacellar, Tais Xastre, Evandro Ivanov, Patrícia Ortolan, Taciana Kolish, Melissa Maranhão, Alexandre Sasaki, Marcelo Rossi, Luciene Lima, Felipe Afonso, Cesar Castro, Cesar Ottani, Bruno Nicolau, Anne Caroline Neves e Pedro Nariyoshi, que me acompanharam nesta jornada e me ajudaram a manter a sanidade nos momentos difíceis.

Às famílias Pasta, Baptista, Zanni e "adendos", que já considero meus familiares e que me proporcionaram muitos bons momentos.

Agradecimentos especiais a toda a minha família, principalmente aos meus pais, que me ofereceram carinho e paciência mesmo em momentos nos quais eu falhei em lhes oferecer os mesmos.

Agradeço principalmente ao meu noivo Vítor, por todo o amor e apoio que me dão forças para enfrentar qualquer desafio.

E a Deus, por ter colocado todas essas pessoas maravilhosas na minha vida. 


\section{RESUMO}

Torelli, N.Q. Sinalização Retrógrada RTG-Dependente Controla a Atividade Mitocondrial e Resistência a Estresse em Saccharomyces cerevisiae. 2014. 58p. Dissertação - Programa de Pós-Graduação em Bioquímica. Instituto de Química, Universidade de São Paulo, São Paulo.

A sinalização retrógrada mitocondrial é uma via de comunicação entre a mitocôndria e o núcleo que regula a expressão de uma série de genes nucleares que codificam proteínas mitocondriais, em resposta a disfunções mitocondriais. Em Saccharomyces cerevisiae, a via depende de $\operatorname{Rtg} 1 p$ e Rtg3p, que juntos formam o fator de transcrição que regula a expressão gênica, e de Rtg2p, um ativador da via. Aqui, nós mostramos novos estudos direcionados à investigação do impacto da sinalização retrógrada RTG-dependente na fisiologia mitocondrial. Verificamos que mutantes incapazes de realizar sinalização retrógrada RTG-dependente apresentam consumo de oxigênio mais elevado e menor produção de peróxido de hidrogênio em fase estacionária quando comparados a células selvagens. Interessantemente, mutantes RTG são menos capazes de decompor peróxido de hidrogênio assim como manter-se viáveis quando desafiados com peróxido. Nossos resultados indicam que a sinalização por RTG está envolvida na indução hormética de defesas antioxidantes e de resistência a estresse, função ainda não descrita para este sistema.

Palavras-chave: Mitocôndria, sinalização retrógrada, RTG, hormese, Saccharomyces cerevisiae 


\begin{abstract}
Torelli, N.Q. RTG-Dependent Retrograde Signaling Controls Mitochondrial Activity and Stress Resistance in Saccharomyces cerevisiae. 2014. 58p. Masters Thesis Graduate Program in Biochemistry. Instituto de Química, Universidade de São Paulo, São Paulo.

Mitochondrial retrograde signaling is a communication pathway between the mitochondrion and the nucleus which regulates the expression of a subset of nuclear genes that codify mitochondrial proteins, mediating cell response to mitochondrial dysfunction. In Saccharomyces cerevisiae, the pathway depends on Rtg1p and Rtg3p, which together form the transcription factor that regulates gene expression, and Rtg2p, an activator of the pathway. Here, we provide novel studies aimed at assessing the functional impact of the lack of RTG-dependent signaling on mitochondrial activity. We show that mutants defective in RTG-dependent retrograde signaling present higher oxygen consumption and reduced hydrogen peroxide release in the stationary phase when compared to wild type cells. Interestingly, RTG mutants are less able to decompose hydrogen peroxide as well as maintain viability when challenged with hydrogen peroxide. Overall, our results indicate that RTG signaling is involved in the hormetic induction of antioxidant defenses and stress resistance, a function of this system not yet described.
\end{abstract}

Keywords: Mitochondria, retrograde signaling, RTG, hormesis, Saccharomyces cerevisiae 


\section{SUMMARY}

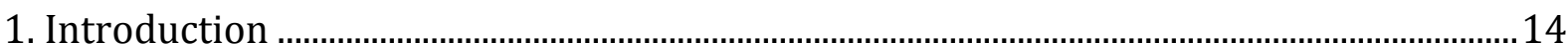

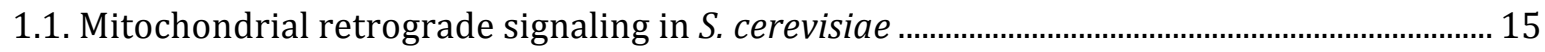

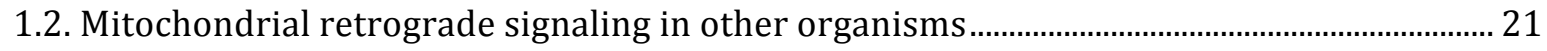

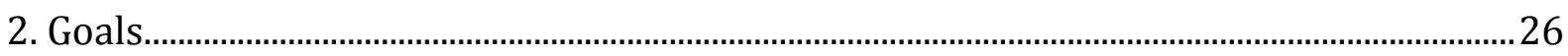

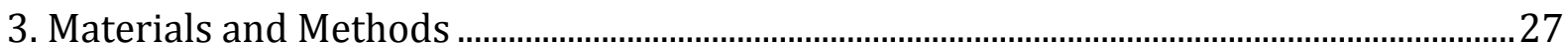

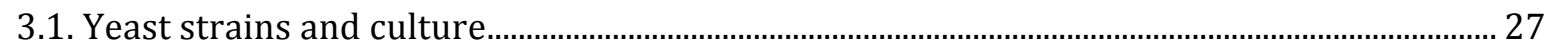

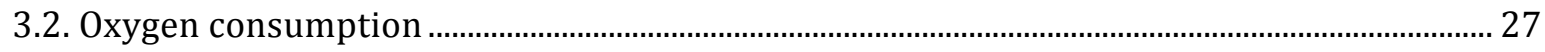

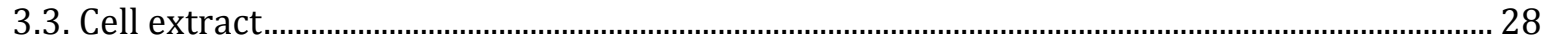

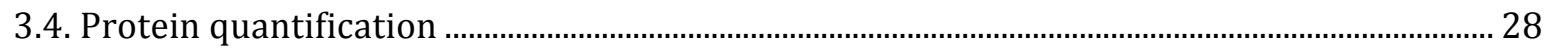

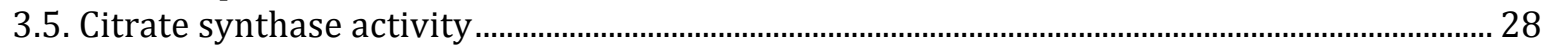

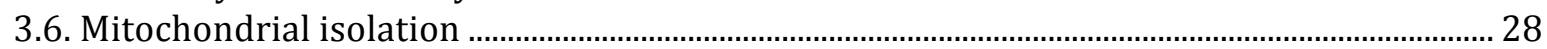

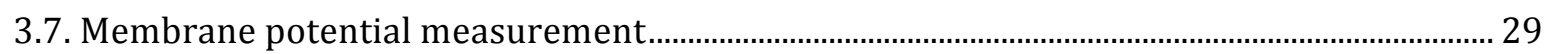

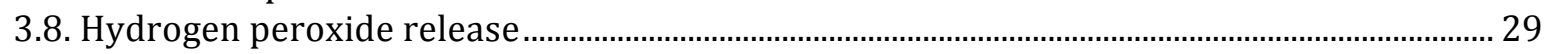

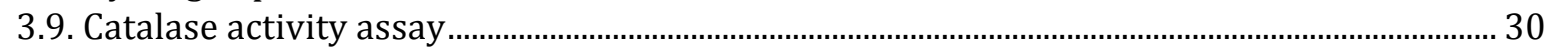

3.11. Total hydrogen peroxide removal activity ............................................................................... 30

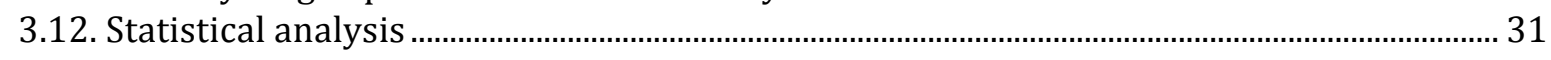

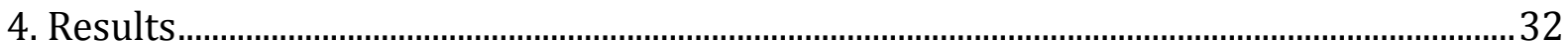

4.1. $r t g \Delta$ mutants present higher mitochondrial activity when grown in YPD............................. 32

4.2. Mitochondria from $r t g \Delta$ mutants grown for 7 days in fermentative medium present

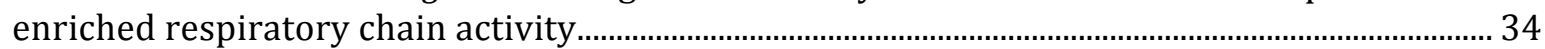

4.3. WT mitochondria release higher levels of $\mathrm{H}_{2} \mathrm{O}_{2}$, promoting enhanced stress resistance .. 37

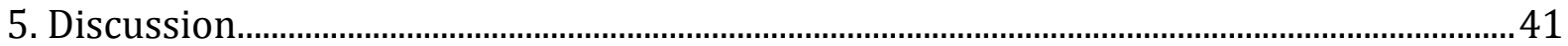

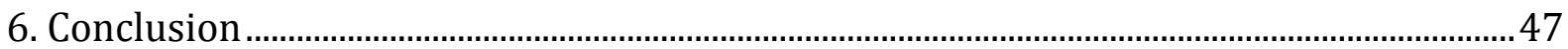

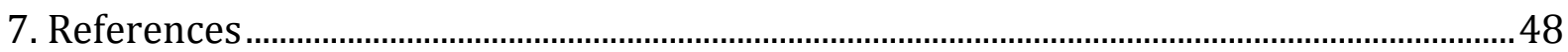

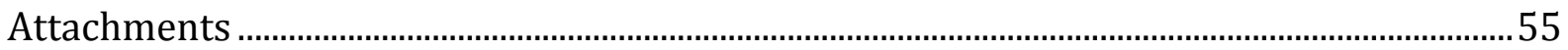

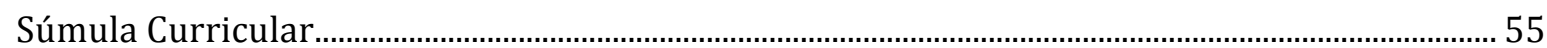




\section{Introduction}

While unquestionably essential for eukaryotic aerobic metabolism, mitochondria are organelles with multiple functions, including the biosynthesis of intermediary metabolites, regulation of cytosolic $\mathrm{Ca}^{2+}$ homeostasis (Deluca and Engstrom, 1961; Vasington and Murphy, 1962; Mallilankaraman et al., 2012a; Mallilankaraman et al., 2012b; Sancak et al., 2013) and coordination of cell death (Hockenbery et al., 1990; Yang et al., 1997; Kroemer et al., 2007), among others. Indeed, many aging-induced processes (for review see Dai et al., 2014) and degenerative diseases (for review see Kamat et al., 2014) are related to mitochondrial dysfunction, highlighting the critical importance of this organelle.

Mitochondria are believed to be former free-living bacteria that established a successful symbiosis with eukaryotic cells billions of years ago (Sagan, 1967). The evolution of this relationship resulted in transfer of genetic material so that, currently, most mitochondrial proteins (but not all of them) are coded in the nucleus. In this scenario, the need for a communication system between mitochondria and the nucleus becomes evident, necessary not only to coordinate mitochondrial protein synthesis during biogenesis but also to communicate eventual mitochondrial malfunctions, triggering compensatory responses in the nucleus. This retrograde communication pathway from mitochondria to the nucleus has been uncovered (Parikh et al., 1987; Liu and Butow, 2006), and regulates organelle quality (Journo et al., 2009) and responses to functional loss through nuclear gene expression control of mitochondrial proteins (Epstein et al., 2001; Traven et al., 2001; Marusish et al., 1997; Wang and Morais, 1997; Butow and Avadhani, 2004; Miceli and Jazwinski, 2005). 


\subsection{Mitochondrial retrograde signaling in S. cerevisiae}

In Saccharomyces cerevisiae, the overall result of regulation through the retrograde pathway modifies the expression of an extensive set of genes (Epstein et al., 2001; Traven et al., 2001), including CIT1 (encoding mitochondrial citrate synthase), CIT2 (peroxissomal citrate synthase), PYC1 (pyruvate carboxylase), ACS1 (acetylcoenzyme A synthetase), ACO1 (aconitase), IDH1/2 (NAD+-dependent isocitrate dehydrogenase) and DLD3 (D-lactate dehydrogenase) (Liao et al., 1991; Liao and Butow, 1993; Liu and Butow, 1999; Chelstowska et al., 1999; Vélot et al., 1996), most of them involved in the synthesis of citric acid cycle intermediates. These genes can be divided in two groups: those that show robust retrograde response (i.e. whose expression is elevated in cells lacking mitochondrial DNA: $\rho^{0}$ petites) and those whose expression is not elevated in $\rho^{0}$ petites, but are $R T G$-target genes.

Two genes that show robust retrograde response are CIT2 and DLD3. CIT2 expression and the activity of peroxissomal citrate synthase are elevated in $\rho^{0}$ petites compared to isochromosomal respiratory competent cells $\left(\rho^{+}\right)$(Liao et al., 1991). DLD3 is also more expressed in $\rho^{0}$ petites, though D-lactate dehydrogenase activity was not compared between respiratory deficient and competent cells (Chelstowska et al., 1999).

CIT1, ACO1 and IDH1/2 show no alterations in transcript levels in cells lacking respiratory capacity, but the control of their expression switch from the HAP system (active in cells with robust mitochondrial function) to the $R T G$ system in cells with reduced or absent mitochondrial respiratory function (Liu and Butow, 1999). Although the expression and activity of CIT1 is unaltered in $\rho^{0}$ petites, the disruption of CIT1 or inhibition of respiratory activity with antimycin $A$ in $\rho^{+}$cells elevates the expression of CIT2, suggesting that retrograde regulation of CIT2 acts as a way to provide citrate 
generated by the glyoxylate cycle to mitochondria when carbon flux through the tricarboxylic acid (TCA) cycle is impaired (Liao et al., 1991). The RTG control of CIT1, ACO1 and IDH1/2 contributes toward $\alpha$-ketoglutarate synthesis and thus ensures that there is sufficient glutamate for biosynthetic pathways in cells with reduced respiratory capacity (Figure 1). Indeed, cells with mutant alleles of RTG1 or RTG2 are unable to grow in acetate as the sole carbon source, a sign of a defective TCA cycle, and are auxotrophic for glutamate or aspartate. Obstructions in the TCA cycle alone do not lead to glutamate or aspartate auxotrophy since its precursors can be provided by intermediates of the glyoxylate cycle. However, RTG1, RTG2 or RTG3 deletion impairs both cycles, thus making cells unable to grow without glutamate or aspartate (Liao and Butow, 1993; Jia et al., 1997). Expression of $C I T 1, C I T 2$ and DLD3 are repressed by glutamate, establishing a feedback regulation of glutamate synthesis that occurs through external amino acid sensing (Liu and Butow, 1999; Liu et al., 2001).

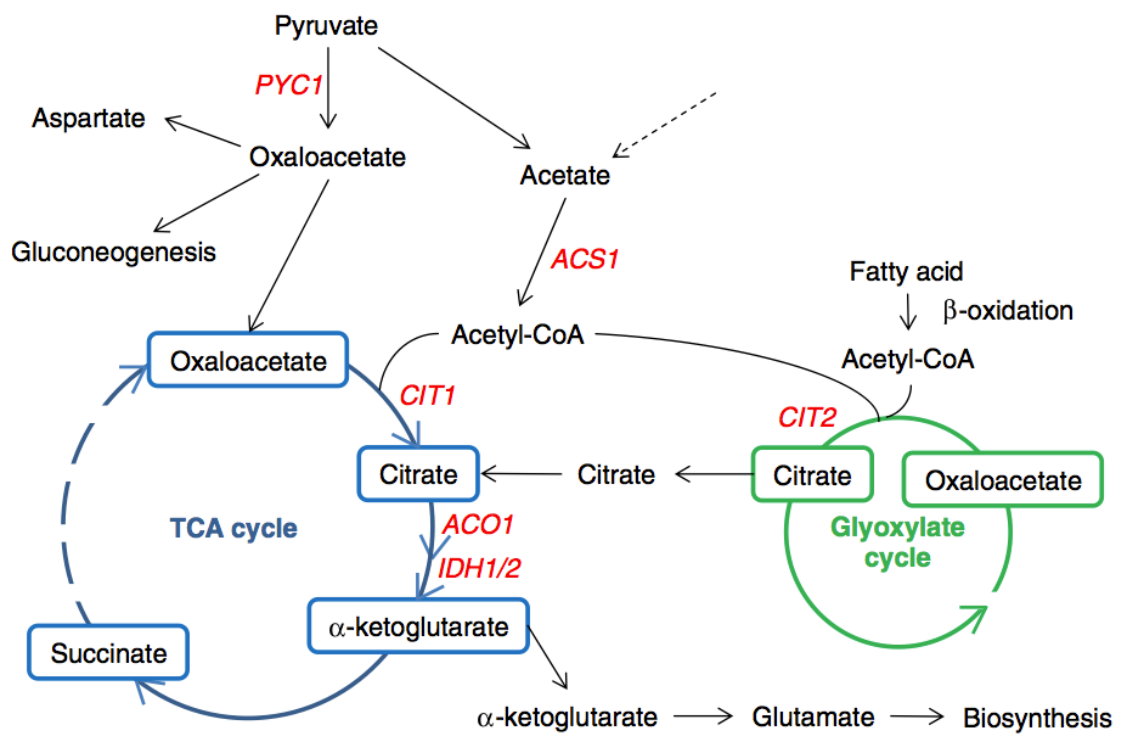

Figure 1. Retrograde signaling promotes the production of TCA cycle intermediates. Mitochondrial dysfunction leads to respiratory deficiency and an impaired TCA cycle (dotted line). Retrograde signaling induces the expression of genes that lead to glutamate synthesis and allows biosynthesis of other metabolites under these conditions. Increased expression of PYC1 (pyruvate carboxylase) promotes conversion from pyruvate to oxaloacetate, which can be used in gluconeogenesis to generate aspartate or produce citrate by CIT1 (mitochondrial citrate synthase). Many genes involved in $ß$-oxidation of fatty acids are also upregulated by retrograde signaling, providing acetate, which is converted to acetyl-CoA due to ACS1 (acetyl-CoA synthetase) expression. ACO1 (aconitase) and IDH1/2 (isocitrate dehydrogenase) upregulation promotes the generation of $\alpha$-ketoglutarate from citrate, that can lead to glutamate 
production, which is used in many biosynthetic pathways. Citrate can also be provided to the mitochondrion from the peroxisome, through induction of the glyoxylate cycle by increased expression of CIT2 (peroxisomal citrate synthase) (Jazwinski, 2012).

The retrograde signaling pathway depends on three cytosolic proteins: Rtg1p, Rtg2p and Rtg3p. Rtg1p and Rtg3p are basic helix-loop-helix/leucine zipper (bHLH/LeuZip) transcription factors that bind as a heterodimer to the GTCAC DNA binding site ( $\mathrm{R}$ box or $\mathrm{UAS}_{\mathrm{r}}$ ). When activated, the Rtg1/3p complex translocates from the cytoplasm to the nucleus (Sekito et al., 2000), where it controls the expression of genes that encode for mitochondrial proteins. CIT1 has one R box (Liu and Butow, 1999), whereas CIT2 and DLD3 have two R boxes in their 5' noncoding regions, both required for maximal gene expression (Liao and Butow, 1993; Chelstowska et al., 1999). Although only Rtg3p contains a transcription activation domain, Rtg1p and Rtg3p are both required for DNA binding.

Rtg1/3p translocation is dependent on partial dephosphorylation of Rtg3p (Sekito et al., 2000). Inhibition of retrograde signaling occurs through the prevention of Rtg3p dephosphorylation mediated by Mks1p, a cytosolic phosphoprotein, when it is hyperphosphorylated and bound to Bmh1/2p. Rtg2p is an activator of the pathway that binds to the hypophosphorylated form of Mks1p, keeping it from binding to Bmh1/2p and allowing partial dephosphorylation of Rtg3p and Rtg1/3p translocation (Sekito et al., 2002; Liu et al., 2003). The phosphoprotein that controls the phosphorylation state of Rtg3p and Mks1p is still unknown. Mks1p thus works through a dynamic switch between Rtg2p and Bmh1/2p: when bound to Rtg2p, retrograde signaling is active; when bound to Bmh1/2p, it is inactive. The Mks1p levels in the cell are controlled by

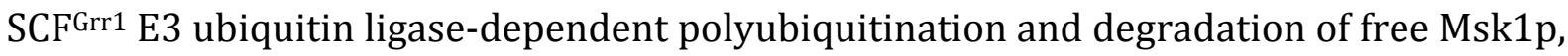
enhancing the efficiency of the Rtg2p/Bmh1/2p switch by keeping the concentration of 
free Mks1p low (Liu et al., 2005). Rtg2p has an N-terminal HSP70-like ATP-binding domain that is required for the interaction with Mks1p (Liu et al., 2003). Mks1p release from Rtg2p is dependent on ATP hydrolysis and is ATP specific, suggesting that loss of mitochondrial DNA activates the pathway possibly through a decrease in ATP concentration, allowing Mks1p-Rtg2p association and Rtg1/3p nuclear translocation (Zhang et al., 2013). Another trigger of the retrograde response is loss of the mitochondrial membrane potential (Miceli et al., 2012).

The retrograde signaling pathway has been found to coordinate carbon and nitrogen metabolism since Rtg1/3p subcellular localization and activity are also regulated by the target of rapamycin (TOR) kinase pathway (Komeili et al., 2000), which favors anabolic or catabolic reactions according to nutrient availability and response to stress. Inhibition of TOR function by rapamycin mimics nutrient starvation and affects genes involved in protein biosynthesis, the glycolytic pathway, the TCA cycle and nitrogen metabolism, including permeases and degradative enzymes required for use of different sources of assimilable nitrogen (Cardenas et al., 1999; Hardwick et al., 1999). Lst8p, a component of the target of rapamycin complex 1 (TORC1), is a negative regulator of the RTG-dependent retrograde signaling pathway (Giannattasio et al., 2005) acting at two sites, one upstream of Rtg2p and one between Rtg2p and Rtg1/3p. Upstream regulation is believed to involve Lst8p in the activity or assembly of the SPS (Ssy1p, Ptr3p, Ssy5p) amino acid-sensing system, affecting external glutamate sensing and consequently the retrograde response (Forsberg et al., 2001; Liu et al., 2001). The mechanism of Lst8p inhibition downstream of Rtg2p remains unknown. Treatment with rapamycin inhibits TOR function and thus activates retrograde signaling, inducing the expression of RTG-target genes (Liu et al., 2001). It is also known that mitochondrial dysfunction leads to decreased phosphorylation and reduced activity of Sch9p (Kawai et 
al., 2011), a target of TORC1 important for ribosome biosynthesis, cell-size control, inhibition of entry into the stationary phase and translation initiation (Urban et al., 2007), another possible link between retrograde signaling and the TOR kinase pathway.

Resistance to osmotic stress is also related to retrograde signaling. Exposure to external hyperosmolarity activates Hog1 stress-activated protein kinase (SAPK), which controls several transcription factors such as Sko1p, Hot1p, Msn2p and Msn4p and Smp1p, that regulate stress response gene expression. Expression of RTG-dependent genes is also induced under osmotic stress and is dependent on Hog1 SAPK. Hog1 SAPK binds to the Rtg1/3p transcription factor and allows its translocation to the nucleus. Hog1 SAPK is also required for Rtg1/3p binding to the chromatin under these conditions. Though only the presence of Hog 1 SAPK is required for Rtg1/3p nuclear translocation, its activity is necessary for the transcription factor to bind to the chromatin (Ruiz-Roig et al., 2012).

Activation of retrograde signaling extends replicative life span (the number of times a cell can divide originating daughter cells) in some yeast strains (Kirchman et al., 1999). Mks1 is a negative regulator of the Ras2-cAMP/PKA pathway (Matsuura and Anraku, 1993), which regulates cell growth and proliferation according to nutrient sensing and stress conditions. The deletion of $R A S 2$ impairs life span extension in a cAMP-independent way (Sun et al., 1994) and abrogates the retrograde response (Kirchman et al., 1999), though how exactly Ras2p acts in the retrograde signaling pathway is not known to date.

Another way by which retrograde signaling possibly contributes to life span extension is through counteraction of negative effects that rise from the age-induced increase in the generation of extrachromosomal rDNA (ribosomal DNA) circles (ERCs) (Jazwinski, 2000). ERCs can lead to unbalanced expression of RNA and titration of 
components of the replication or transcription machinery, resulting in inability to replicate or transcribe genomic DNA (Sinclair and Guarente, 1997). Rtg2p is responsible for coordinating ERCs formation and the response to their production through retrograde signaling. When retrograde signaling is repressed, Rtg2p suppresses ERC generation, but as cells age and accumulating mitochondrial dysfunction activates retrograde signaling, $\mathrm{Rtg} 2 \mathrm{p}$ is recruited by this pathway and ERC formation can take place (Bourghouts et al., 2004). The retrograde response, however, alleviates ERCs deleterious effects to some extent, which explains how petite cells can present longer life span (Kirchman et al., 1999) in spite of higher ERCs generation (Conrad-Webb and Butow, 1995).

Some data suggest that RTG signaling may also be involved in selective autophagy. General autophagy is a pathway that controls cell quality by removing proteins and organelles in a regulated, non-selective, manner (Nagatogawa et al., 2009). A selective process that targets dysfunctional mitochondria through the Atg32p protein is called mitophagy (Lemasters, 2005; Kim et al., 2007; Kissova et al., 2007). Stationary phase mitophagy, a process that occurs under physiological conditions in an unperturbed yeast culture (Tal et al., 2007), requires the AUP1 gene, which is also necessary for Rtg1/3p nuclear translocation and upregulation of CIT2 and DLD3 in response to histidine biosynthesis inhibition, a signal known to activate retrograde signaling (Giannattasio et al., 2005). On the other hand, Rtg3p is required for mitophagy, but not general autophagy, showing that there are mechanistic differences between the general and selective process and that retrograde signaling is involved in mitochondrial degradation (Journo et al., 2009). 
It is therefore clear that retrograde signaling is related to a number of signal transduction events and physiological processes (Figure 2) that together are crucial for cell adaptation to a variety of internal and external environmental conditions.

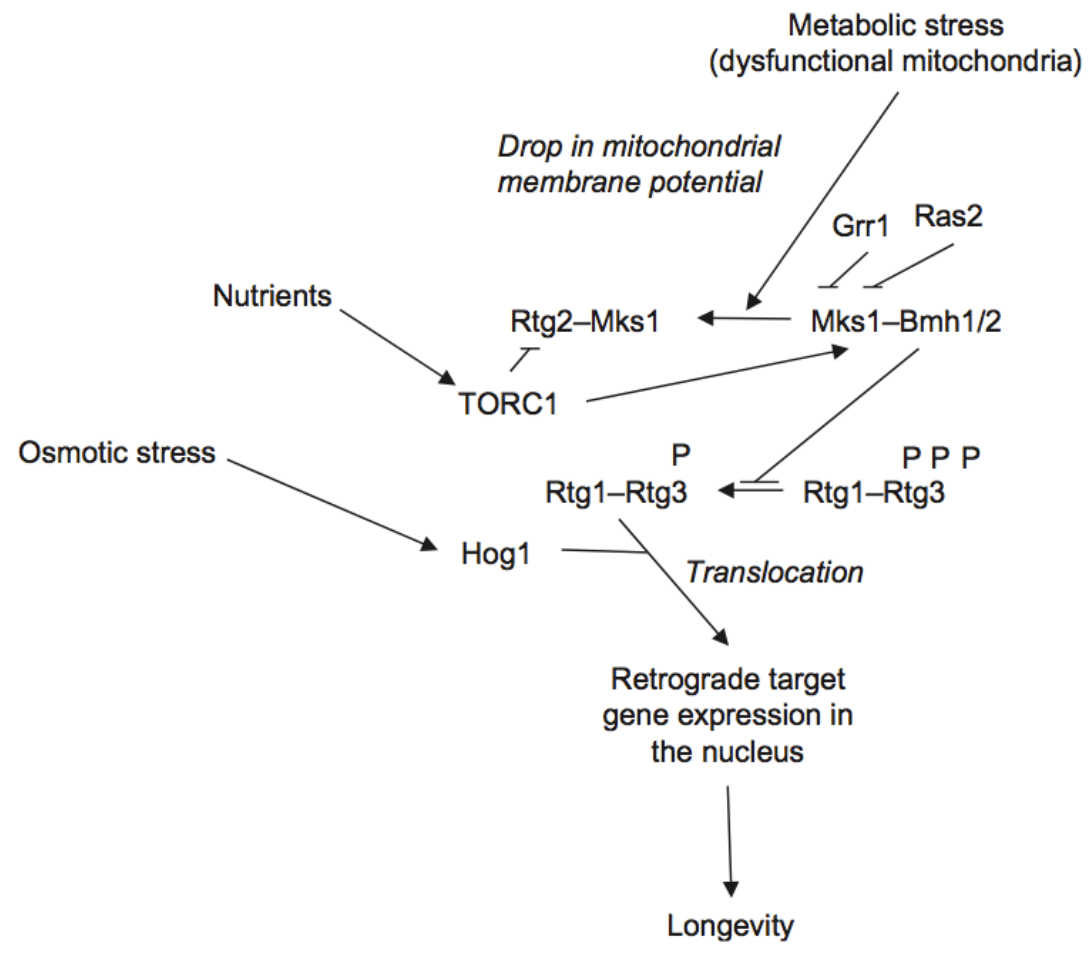

Figure 2. RTG-dependent retrograde signaling in Saccharomyces cerevisiae. Metabolic or osmotic stress promotes activation of the RTG pathway: Rtg3p becomes partially dephosphorylated, allowing Rtg1/3p nuclear translocation, where it regulates the expression of genes that encode enzymes from the glyoxylate and tricarboxylic acid cycles. Mks1p inactivates the pathway when bound to Bmh1/2p, preventing Rtg3p dephosphorylation and Rtg1/3p translocation. Retrograde signaling is activated when Mks1p is bound to Rtg2p instead of Bmh1/2p. Hog1p induces the retrograde response to stress by promoting Rtg1/3p translocation. Grr1p and Ras $2 p$ also contribute toward the activation of the pathway: Grr1p promotes Mks1p degradation and the molecular mechanisms by which Ras $2 \mathrm{p}$ acts in the signaling pathway are still unknown, but deletion of RAS2 abrogates retrograde signaling. Nutrient availability regulates the pathway through TORC1, which inhibits Rtg2p, thus allowing Mks1p/Bmh1/2p binding and blocking the retrograde response. Retrograde signaling regulation of gene expression is known to promote longevity in some cases (Jazwinski, 2014).

\subsection{Mitochondrial retrograde signaling in other organisms}

Although through different molecular mechanisms, many still not well characterized, mitochondria-to-nucleus communication is found in other organisms besides yeast. In Drosophila melanogaster, RNAi knockdown of several respiratory chain components led to increased life span in many strains (Copeland et al., 2009). A mutant 
in the sbo gene, defective in coenzyme Q synthesis, also presented extended longevity (Liu et al., 2011). The signaling pathways, however, were not identified. In mouse, reduced activity of $M C L K 1$, involved in coenzyme $\mathrm{Q}$ synthesis, also substantially increased life span (Lapointe and Hekimi, 2008), as did SURF1 knockout, which disrupts mitochondrial complex IV assembly (Dell'agnelo et al., 2007). Once again, how the signal transduction occurs is still not characterized.

A retrograde response has also been identified in Caenorhabditis elegans. The glyoxylate cycle becomes upregulated with age and mutants in the age-1 and daf-2 genes show increased life span (Vanfleteren and De Vreese, 1995); this is proposed to occur due to retrograde signaling (Kirchman et al., 1999). Confirmation for this hypothesis comes from the finding that knockdown of respiratory chain components can extend life span (Dillin et al., 2002; Lee et al., 2003; Cristina et al., 2009), though disruption of the electron transport chain (ETC) at different sites leads to different associated phenotypes (Yang and Hekimi, 2010). Knockdown of cco-1, encoding a subunit of mitochondrial cytochrome oxidase, extends worm life span by activating the hypoxia-inducible transcription factor HIF-1, and this response is triggered by mild increases in mitochondrial reactive oxygen species (ROS) production (Lee et al., 2010). However, other triggering factors have been reported. Mitochondrial unfolded protein response also plays a role in longevity promoted by alterations in the ETC through action of the UBL-5 and DVE-1 transcription factors that respond to mitochondrial perturbations increasing the expression of chaperones such as $h s p-6$ and $h s p-60$. The fact that this happens in a nonautonomous cell setting suggests the presence of diffusible mitokines that, when produced by a limited number of cells, can influence the survival of the entire organism (Durieux, 2011). Another study shows that the nuclear homeobox transcription factor $\mathrm{CEH}-23$ modulates life span extension resulting from an impaired 
ETC (Walter et al., 2011). All these studies showed that the transcription factors are necessary and sufficient for life span extension, but the mutual relationship between these pathways is not clear, indicating that in $C$. elegans retrograde signaling occurs through a set of different molecular mechanisms, possibly due to the lack of a signaling molecule to which the mechanisms converge, such as NFkB.

$\mathrm{NF \kappa B}$ is a conserved master regulator present in mammals that responds to a variety of stress conditions, immune signaling, organelle dysfunction and aging (Srinivasan et al., 2010) and exerts epigenetic effects in various processes, mainly DNA methylation that results in gene silencing (Vanden Berghe et al., 2006). NFkB knockout mice present reduced life span (Lu et al., 2006). NFKB and mTOR act in parallel to trap the cell in a low-energy supplying state when there is reduced ATP biosynthesis (Srinivasan et al., 2010), demonstrating that NFKB orchestrates many signaling pathways in response to unfavorable conditions. The absence of a NFKB homolog in $C$. elegans acting as a central stress regulator could explain why there are three different, necessary and sufficient retrograde responses in this organism (Jazwinski, 2014).

Altered nuclear expression in response to mitochondrial dysfunction has long been reported in mammalian cells (Marusish et al., 1997; Wang and Morais, 1997). Calcium and NFKB signaling have been implicated in this retrograde communication (Butow and Avadhani, 2004). In mammals, mitochondria play a key role in intracellular $\mathrm{Ca}^{2+}$ signaling by taking up $\mathrm{Ca}^{2+}$ released from intracellular storage sites or from outside the cell, storing it transiently and releasing it to the cytoplasm (Rizzuto et al., 1993; Babcock et al., 1997; Ichas et al., 1997). Disruption of mitochondrial membrane potential impairs mitochondrial $\mathrm{Ca}^{2+}$ uptake and causes an elevation in free $\mathrm{Ca}^{2+}$ in the cytoplasm (Luo et al., 1997; Biswas et al., 1999; Amuthan et al., 2002; Arnould et al., 2002). This elevation activates $\mathrm{Ca}^{2+}$-dependent protein quinase C (PKC), CamKIV, JNK and MAPK, 
which then activate the transcription factors ATF2, CEBP/ $\delta$, CREB, Egr-1 and CHOP (Butow and Avadhani, 2004). The latter is involved in mitochondrial stress response to aggregated ornitine decarboxylase, possibly in a similar manner to C. elegans mitochondrial unfolded protein response, only depending on CHOP instead of UBL-5 and DVE-1 homologues (Zhao et al., 2002). Elevated $\mathrm{Ca}^{2+}$ levels also activate calcineurin, a calcium-dependent serine-threonine phosphatase that induces NFAT and NFKB. Dephosphorylation and consequently inactivation of $\mathrm{IkB} ß$ activates of $\mathrm{NF \kappa B}$ and releases NFKB/Rel dimers, which translocate to the nucleus (Biswas et al., 2003).

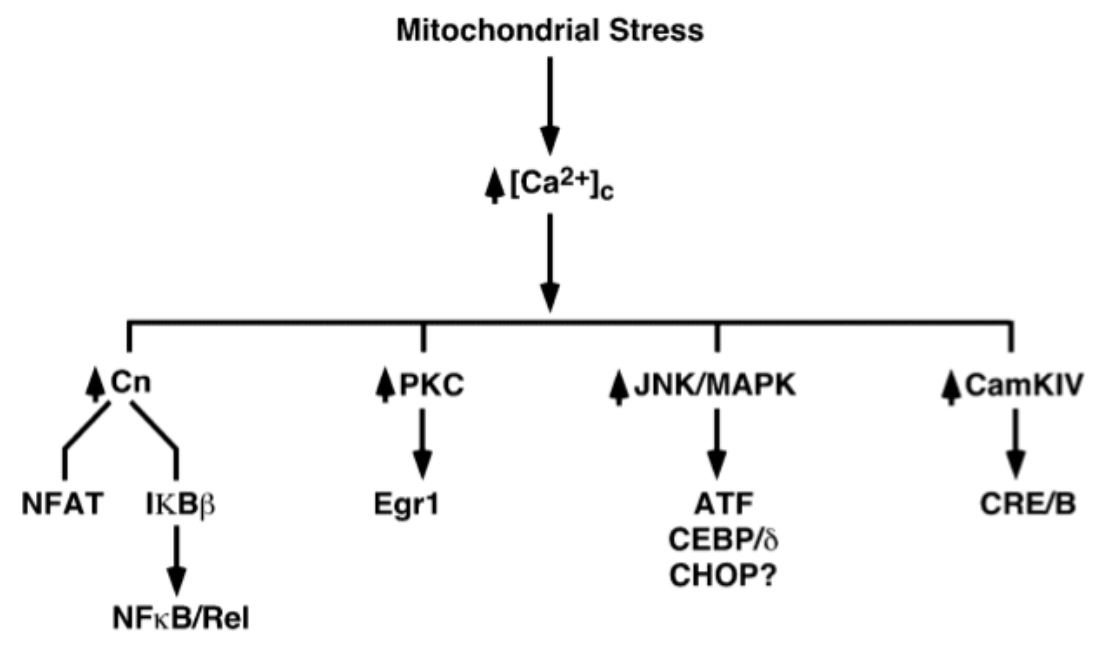

Figure 3. Activation of cytoplasmic and nuclear factors in mammals in response to mitochondrial stress. Mitochondrial stress induces increases in cytoplasmic calcium concentrations, which activate calcium-dependent phosphatase calcineurin ( $\mathrm{Cn}$ ) and PKC, JNK/MAPK and CamKIV, that in turn activate different nuclear transcription factors that promote the expression of stress response genes (Butow and Avadhani, 2004).

The gene expression profiles of $\rho^{0} / \rho^{+}$pairs of human cells derived from different cell layers were compared (Miceli and Jazwinski, 2005) and, although they were very heterogeneous, there were some common genes whose expression was altered in response to the lack of mitochondrial respiratory activity. One of these genes was c-Myc, a bHLH/LeuZip transcription factor involved in the shift to glycolytic metabolism and whose expression is activated under these conditions (Collier et al., 2003). It is believed 
that NFkB acts upstream of c-Myc in the mammalian retrograde response, since it has two binding sites in the Myc promoter (Duyao et al., 1990).

The mammalian Myc/Max heterodimeric transcription factor is homologous to the yeast Rtg1/3 (Srinivasan et al., 2010), but to date Rtg2p has no homolog in higher organisms. There are several difficulties in finding homology between signaling proteins across different organisms because of the lack of knowledge of their upstream regulators and of the biochemical activity of regulators such as Mks1p. Even for known homologs, not all protein domains are well characterized, making it difficult to understand the structure and function of each domain. Still, strong homologies between inhibitors and pathways of the $R T G$ genes in $S$. cerevisiae and NFkB suggest that RTGdependent retrograde signaling is a potential predecessor of the master regulator $\mathrm{NF} \kappa \mathrm{B}$ in higher eukaryotes (Srinivasan et al., 2010; Jazwinski and Kriete, 2012). 


\section{Goals}

Though the molecular mechanism of RTG-dependent retrograde signaling and resulting changes in expression are well characterized in $S$. cerevisiae, little is known about the impact on mitochondrial function beyond the alterations in gene expression. Here we aim to study the contribution of Rtg1p and Rtg2p toward mitochondrial functional maintenance. 


\section{Materials and Methods}

\subsection{Yeast strains and culture}

The wild type PSY142 strain of Saccharomyces cerevisiae (MAT $\alpha$ ura3 leu2 lys $2 \rho^{+}$), the null mutant for the RTG1 gene (rtg1::LEU2) as well as the null mutant for the RTG2 gene (rtg2::URA3) were stored at $-80^{\circ} \mathrm{C}$ in $20 \%$ glycerol in liquid YPD (1\% yeast extract, $2 \%$ peptone, $2 \%$ dextrose). Cells were grown in solid YPD (1\% yeast extract, $2 \%$ peptone, $2 \%$ dextrose, $2 \%$ agar) plates for 2 days then kept at $4^{\circ} \mathrm{C}$ for up to 1 month, after which new plates were prepared. For assays, pre-cultures were grown either in liquid YPD or YPEG (1\% yeast extract, 2\% peptone, 2\% dextrose, 2\% glycerol) for $24 \mathrm{~h}$ and used to make a cell suspension in the same culture medium with an $\mathrm{OD}_{600}=0.01$ (optical density). Cells were collected after 16 hours, 3 or 7 days of culture, as specified in the figures.

\subsection{Oxygen consumption}

Respiration rates of $10^{6}$ intact cells (amount used in each measurement) grown for 16 hours, 3 days or 7 days in YPD or $5 \times 10^{5}$ cells grown for the same time periods in YPEG were measured in $\mathrm{KH}_{2} \mathrm{PO}_{4} / \mathrm{K}_{2} \mathrm{HPO}_{4} 0.1 \mathrm{M} \mathrm{pH=7}$ buffer using an Oroboros (Innsbuck, Austria) high-resolution oxygraph (Hütter et al., 2006). For isolated mitochondria from cells grown for 3 or 7 days in YPD, measurements used $20 \mu \mathrm{g} / \mathrm{mL}$ protein in $0.6 \mathrm{M}$ manitol, $10 \mathrm{mM} \mathrm{K} \mathrm{HPO}_{4}, 2 \mathrm{mM} \mathrm{MgCl}$, $20 \mathrm{mM}$ Hepes, $\mathrm{pH}=6.8$ in the presence of $1 \%$ ethanol, $0.2 \mu \mathrm{M}$ cytochrome $\mathrm{c}$ and sequential additions of $2 \mathrm{mM}$ ADP, $1.9 \mu \mathrm{M}$ oligomycin and $2.5 \mu \mathrm{M}$ CCCP (carbonyl cyanide 3-chlorophenylhydrazone). The respiratory rate in the presence of $1.8 \mu \mathrm{M}$ antimycin (non-mitochondrial oxygen consumption) was subtracted from all values. 


\subsection{Cell extract}

Cell extracts for citrate synthase activity, catalase activity and total hydrogen peroxide decomposition measurements were prepared from cells grown for 3 or 7 days in YPD or YPEG (as indicated in the figures) by lysis with glass beads in $0.1 \mathrm{M}$ Tris- $\mathrm{Cl}, \mathrm{pH}=8$ with protease inhibitor, for 1 hour at $4^{\circ} \mathrm{C}$. Debris were removed by centrifugation at $1000 \mathrm{xg}$ at $4^{\circ} \mathrm{C}$ for 10 minutes.

\subsection{Protein quantification}

All protein quantifications were performed according to Bradford (Bradford, 1976).

\subsection{Citrate synthase activity}

Enzymatic activities of $50 \mu \mathrm{g} / \mathrm{mL}$ of cell extract were monitored through the reaction of CoA-SH with DNTB (5,5'-dithiobis-2-nitrobenzoate) after adding acetil-CoA, oxaloacetate and DNTB to the extract and assessing TNB (5-thio-2-nitro-benzoic acid) formation through its absorbance at $412 \mathrm{~nm}\left(\varepsilon=13.6 \mathrm{mM}^{-1} \mathrm{~cm}^{-1}\right)$ (Srere, 1969).

\subsection{Mitochondrial isolation}

Mitochondria were isolated from yeast grown in YPD for 3 or 7 days. Cells were pretreated at $30^{\circ} \mathrm{C}$ with $0.1 \mathrm{M}$ Tris- $\mathrm{Cl}, 0.1 \mathrm{M}$ 2-mercaptoethanol, $\mathrm{pH}=9.4$ at $0.25 \mathrm{~g}$ cells/mL for 15 minutes, then washed twice with $50 \mathrm{mM}$ Tris-Cl, $0.1 \mathrm{M} \mathrm{KCl}, \mathrm{pH}=6.8$ and suspended at $0.15 \mathrm{~g}$ cells/mL in lysis buffer (1.2 M Sorbitol, $20 \mathrm{mM} \mathrm{K} \mathrm{HPO}_{4} / \mathrm{KH}_{2} \mathrm{PO}_{4}$, $\mathrm{pH}=7.4$ ) containing $2500 \mathrm{U} / \mathrm{mg}$ zymolyase. Cells were incubated at $30^{\circ} \mathrm{C}$ in a shaker for 40 minutes with the formation of spheroplasts monitored by absorbance (Zinser and Daum, 1995) and then centrifuged at $3200 \mathrm{x}$ g at $4^{\circ} \mathrm{C}$ for 3 minutes. The pellet was 
washed with lysis buffer and suspended in $0.3 \mathrm{M}$ manitol, $20 \mathrm{mM}$ Hepes, $0.1 \%$ BSA, $\mathrm{pH}=6.8$, homogenized using a Dounce homogeneizer (15 strokes) and then suspended in $0.6 \mathrm{M}$ manitol, $20 \mathrm{mM}$ Hepes, $0.1 \% \mathrm{BSA}, \mathrm{pH}=6.8$. Sequential centrifugations at $1486 \mathrm{x} \mathrm{g}$ (5 min), $12857 \times \mathrm{g}(10 \mathrm{~min}), 3214 \times \mathrm{g}(5 \mathrm{~min})$ and $18514 \times \mathrm{g}(10 \mathrm{~min})$ were then conducted at $4^{\circ} \mathrm{C}$. Mitochondria were gently suspended in either $0.6 \mathrm{M}$ manitol, $10 \mathrm{mM}$ $\mathrm{K}_{2} \mathrm{HPO}_{4}, 2 \mathrm{mM} \mathrm{MgCl}$, $20 \mathrm{mM}$ Hepes, $\mathrm{pH}=6.8$ (for respiration assays) or $0.6 \mathrm{M}$ manitol, 10 $\mathrm{mM} \mathrm{H}_{3} \mathrm{PO}_{4}, 2 \mathrm{mM} \mathrm{MgCl}$, $20 \mathrm{mM}$ Hepes, $\mathrm{pH}=6.8$ (for membrane potential and hydrogen peroxide release assays).

\subsection{Membrane potential measurement}

Membrane potentials were estimated in isolated mitochondrial suspensions $(20 \mu \mathrm{g} / \mathrm{mL})$ in the presence of safranin 0 , by monitoring fluorescence changes $\left(\lambda_{\mathrm{ex}}=485 \mathrm{~nm}, \lambda_{\mathrm{em}}=586\right.$ $\mathrm{nm})$. Media contained assay buffer (0.6 M manitol, $10 \mathrm{mM} \mathrm{H}_{3} \mathrm{PO}_{4}, 2 \mathrm{mM} \mathrm{MgCl}_{2}, 20 \mathrm{mM}$ Hepes, $\mathrm{pH}=6.8), 1 \%$ ethanol, $0.2 \mu \mathrm{M}$ cytochrome $\mathrm{c}$, and sequential additions of $2 \mathrm{mM}$ ADP, $1.9 \mu \mathrm{M}$ oligomycin and $3.8 \mu \mathrm{M}$ CCCP. Calibrations were conducted for every experiment in the presence of $1 \%$ ethanol by adding $\mathrm{KCl}$ at known concentrations (Akerman and Wilkström 1976) and applying the Nernst Equation, considering $\left[\mathrm{K}^{+}\right]_{\text {intramitochondrial }}=150 \mathrm{mM}$ (Kowaltowski et al., 2002).

\subsection{Hydrogen peroxide release}

Fluorimetric quantification of the Amplex Red oxidized product resorufin $\left(\lambda_{\mathrm{ex}}=570 \mathrm{~nm}\right.$, $\lambda_{\mathrm{em}}=585 \mathrm{~nm}$ ) was conducted using $20 \mu \mathrm{g} / \mathrm{mL}$ of isolated mitochondria in $0.6 \mathrm{M}$ manitol, $10 \mathrm{mM} \mathrm{H}_{3} \mathrm{PO}_{4}, 2 \mathrm{mM} \mathrm{MgCl}_{2}, 20 \mathrm{mM}$ Hepes, $\mathrm{pH}=6.8$ in the presence of $10 \mu \mathrm{L}$ of $200 \mathrm{U} / \mathrm{mL}$ horseradish peroxidase, $1 \%$ ethanol, $0.2 \mu \mathrm{M}$ cytochrome c, and sequential additions of 
$2.5 \mathrm{mM}$ ADP, $1.9 \mu \mathrm{M}$ oligomycin, $3.8 \mu \mathrm{M}$ CCCP and $1.8 \mu \mathrm{M}$ antimycin. Calibration was conducted using known concentrations of $\mathrm{H}_{2} \mathrm{O}_{2}$ (Ferranti et al., 2003)..

\subsection{Catalase activity assay}

Catalase activity was monitored by measuring oxygen production using a highresolution oxygraph (Oroboros, Innsbuck, Austria) from $0.5 \mathrm{mg} / \mathrm{mL}$ of cell extract in 0.1 M Tris-Cl, $\mathrm{pH}=8$ in the presence of $0.2 \mathrm{mM}$ added $\mathrm{H}_{2} \mathrm{O}_{2}$.

\subsection{Glutathione peroxidase assay}

Glutathione peroxidase activity was monitored by the decrease in NADPH absorbance at $340 \mathrm{~nm}$ during its reaction with glutathione dissulfide (GSSG) (Esworthy et al., 1999) using a 96 well plate. Glutathione (GSG; $10 \mathrm{mM}$ ) and $5 \mathrm{mM} \mathrm{H}_{2} \mathrm{O}_{2}$ were added to 75 $\mu \mathrm{g} / \mathrm{mL}$ of cell extract in $50 \mathrm{mM} \mathrm{KH} \mathrm{KHO}_{4} / \mathrm{K}_{2} \mathrm{HPO}_{4}, \mathrm{pH}=7$ so that intrinsic glutathione peroxidase could generate GSSG. NADPH (2 mM) and $100 \mathrm{U} / \mathrm{ml}$ glutathione reductase were added to convert GSSG to GSH, so that glutathione peroxidase activity could be monitored by NADPH consumption.

\subsection{Total hydrogen peroxide removal activity}

Hydrogen peroxide removal activity was measured by exposing $5 \mathrm{mg} / \mathrm{mL}$ of cell extract in $0.1 \mathrm{M}$ Tris- $\mathrm{Cl}, \mathrm{pH}=8$ to $2 \mu \mathrm{M} \mathrm{H}_{2} \mathrm{O}_{2}$ for 10 minutes, then measuring the initial and remaining $\mathrm{H}_{2} \mathrm{O}_{2}$ content using the Amplex Red oxidized product resorufin $\left(\lambda_{\mathrm{ex}}=570 \mathrm{~nm}\right.$, $\left.\lambda_{\mathrm{em}}=585 \mathrm{~nm}\right)$. 


\subsection{Statistical analysis}

Data are presented as averages \pm SEM. $r t g \Delta$ mutants were individually compared to WT. Statistical analysis and comparisons were performed using unpaired Student tests conducted by GraphPad Prism software. 


\section{Results}

\section{1. $r t g \Delta$ mutants present higher mitochondrial activity when grown in YPD}

To characterize possible differences in mitochondrial activity between wild type (WT) cells and rtg $\Delta$ mutants, respiratory rates of intact cells were measured. Experiments were conducted after 16 h, 3 days and 7 days of culture to include an analysis of the effect of the RTG pathway on mitochondrial maintenance over time. Interestingly, when grown in fermentative medium (YPD) WT cells (Figure 4, white bars) showed a varied pattern of oxygen consumption over time, with an increase at 3 days and subsequent decrease at 7 days. This pattern was previously described for other S. cerevisiae strains (Tahara et al., 2013) grown in YPD: at 16 hours, glucose is predominantly fermented, so respiration is low, while at 3 days cells aerobically consume ethanol generated by previous fermentation. After 7 days of culture, stationary cells present decreased respiratory rates because of reduced overall substrate availability (Tal et al., 2007). The rtg $\Delta$ mutants (Figure 4A grey bars), however, maintained significantly higher respiratory rates at 7 days, demonstrating that the absence of RTG-dependent retrograde signaling prevents the cell from reducing mitochondrial activity when substrate availability is low. When grown in respiratory medium (YPEG), no difference in respiratory activity between WT and $r \operatorname{tg} \Delta$ cells was found (Figure 4C), indicating that the substrate shift from fermentative to respiratory demands an increase in mitochondrial activity that cannot later on be reduced by cells defective in retrograde signaling.

In order to verify if the respiratory rates measured were due to overall mitochondrial activity, the activity of citrate synthase, a citric acid cycle enzyme and marker of mitochondrial mass (Cerqueira et al., 2012), was quantified at 7 days (Figure 
4B and 4D). Both rtg $\Delta$ mutants presented higher citrate synthase activity in YPD, confirming that increased oxygen consumption was due to higher mitochondrial content. The activity was similar in YPEG, in agreement with the respiratory rate results. Since no difference in mitochondrial activity was observed in cells grown in YPEG, all further experiments were conducted with cells grown in YPD.
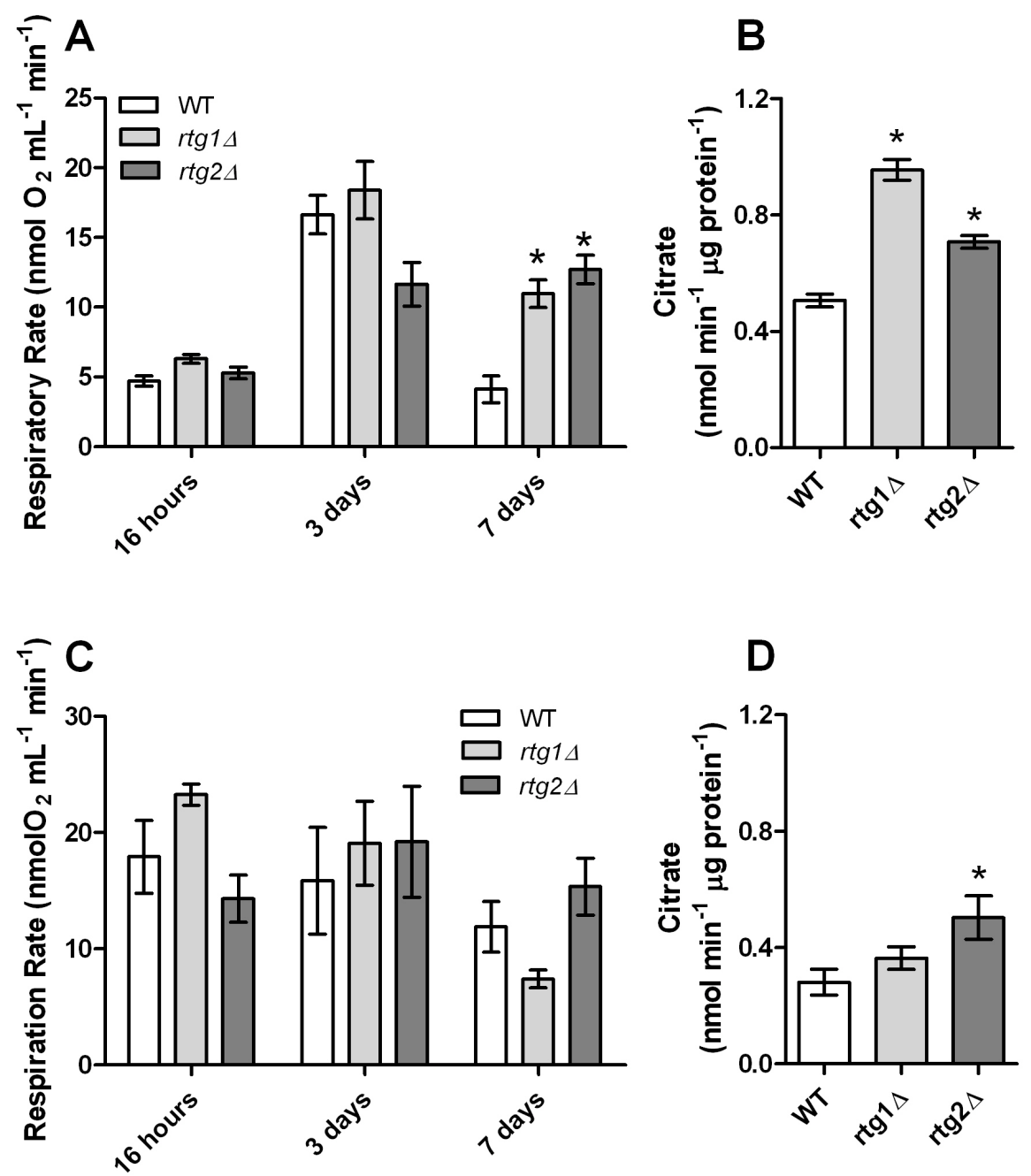

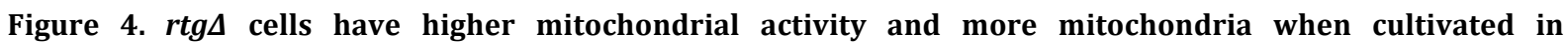
fermentative, but not respiratory, media. (A) Respiratory rates of $10^{6}$ intact cells grown in YPD for 16 hours, 3 days or 7 days. (B) Citrate synthase activities of cells grown for 7 days in YPD. (C) Respiratory rates of $5 \times 10^{5}$ cells grown in YPEG for 16 hours, 3 days or 7 days. (D) Citrate synthase activity of cells grown for 7 days in YPEG. Respiratory rates and citrate synthase activity were measured as described in Materials and Methods. The data represent the averages \pm SEM for three independent cultures. ${ }^{*} \mathrm{p}<0.05$ compared to WT (t-test). 


\subsection{Mitochondria from $r \operatorname{tg} \Delta$ mutants grown for 7 days in fermentative medium present enriched respiratory chain activity}

In order to verify the functional state of mitochondria, we isolated these organelles from cells grown in YPD for 7 days (Figure 5) and measured their ethanolsupported oxygen consumption rates under basal conditions (ethanol, EtOH), in the presence of enhanced ATP synthesis (promoted by added ADP), in the absence of ATP synthesis (promoted by the addition of the ATP synthase inhibitor oligomycin) and with the addition of the uncoupler CCCP, which promotes maximal respiratory rates. We found that $r t g \Delta$ mutant mitochondria present higher respiratory rates under all conditions tested (Figure 5A). Because these experiments were conducted with isolated mitochondria and normalized to mitochondrial protein content, the results indicate that, in addition to presenting higher mitochondrial mass (Figure 4), rtg $\Delta$ mutant mitochondria present enhanced respiratory chain activity relative to the total mitochondrial protein. These changes were not related to altered mitochondrial isolation quality (Nicholls and Ferguson, 2013), since no differences in respiratory control ratios (Figure 5B) were observed. Furthermore, no biologically significant differences in membrane potential were measured, indicating that membrane integrity is unaffected by RTG deletions (Figure 5C). 
A

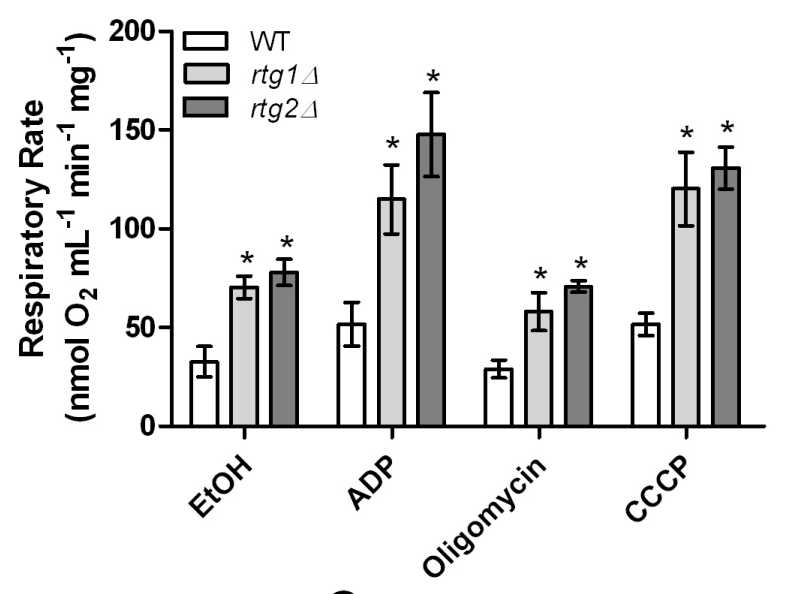

B

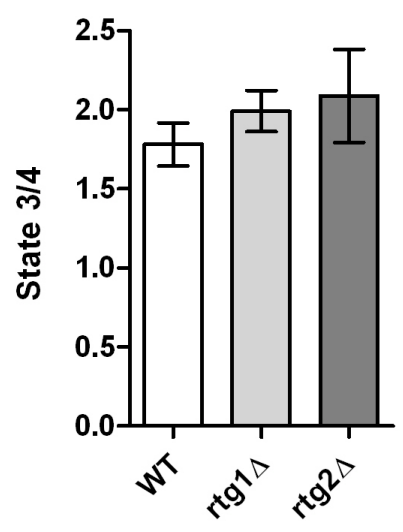

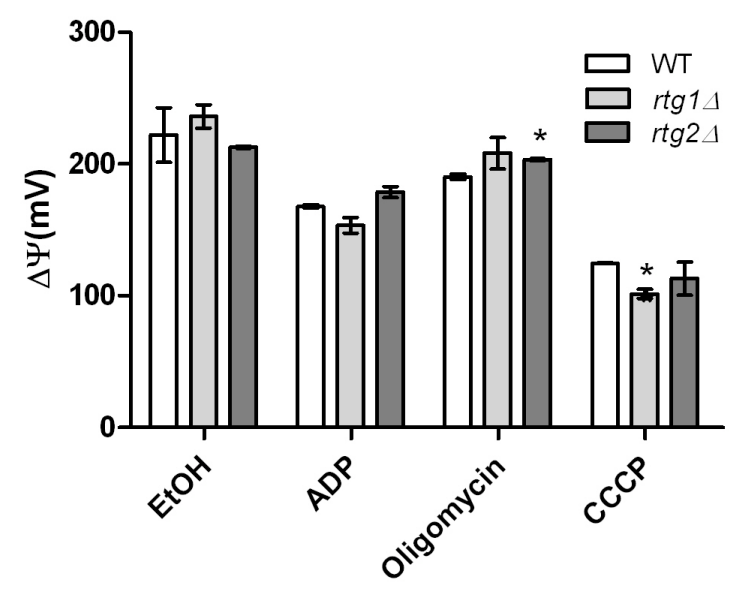

Figure 5. Mitochondria from rtg $\Delta$ cells grown for 7 days present higher respiratory rates, but unchanged respiratory control ratios and similar membrane potentials. (A) Respiratory rates of isolated mitochondria extracted from cells grown in YPD for 7 days were determined as described in Materials and Methods. Measurements were conducted in the presence of $1 \%$ ethanol, $0.2 \mu \mathrm{M}$ cytochrome $\mathrm{c}$ and sequential additions of $2 \mathrm{mM}$ ADP, $1.9 \mu \mathrm{M}$ oligomycin and $2.5 \mu \mathrm{M}$ CCCP. The respiratory rate in the presence of $1.8 \mu \mathrm{M}$ antimycin (non-mitochondrial oxygen consumption) was subtracted from all values. (B) Respiratory controls of isolated mitochondria grown for 7 days in YPD medium were calculated as rates in the presence of ethanol and ADP (state 3) divided by rates in the presence of ethanol, ADP and oligomycin (state 4). (C) Membrane potentials in isolated mitochondria extracted from cells grown for 7 days in YPD were determined as described in Materials and Methods. Measurements were conducted in the presence of $1 \%$ ethanol, $0.2 \mu \mathrm{M}$ cytochrome $\mathrm{c}$ and sequential additions of $2 \mathrm{mM}$ ADP, $1.9 \mu \mathrm{M}$ oligomycin and $3.8 \mu \mathrm{M}$ CCCP. The data represent the averages \pm SEM for three independent cultures. ${ }^{*} \mathrm{p}<0.05$ compared to WT (t-test).

To check if these differences in the functional state of mitochondria were present when cells were grown for less than 7 days, the same experiment was conducted with mitochondria isolated from cells grown in YPD for 3 days (Figure 6). In this case, there were no differences in oxygen consumption between WT and $r t g \Delta$ mitochondria in either condition tested, indicating that retrograde signaling is involved not only in 
adjusting mitochondrial activity of the whole cell, but also in regulating the functional state of the mitochondrion to substrate availability. In addition to reducing mitochondrial activity of the whole cell in response to substrate depletion (Figure 4A), WT cells also lower the oxygen consumption by each mitochondrion in these conditions (Figures 6A and 5A), while rtg $\Delta$ mitochondria do not. Once again these results were unrelated to altered mitochondrial isolation quality (Figure 6B), or to differences in membrane integrity (Figure 6C).

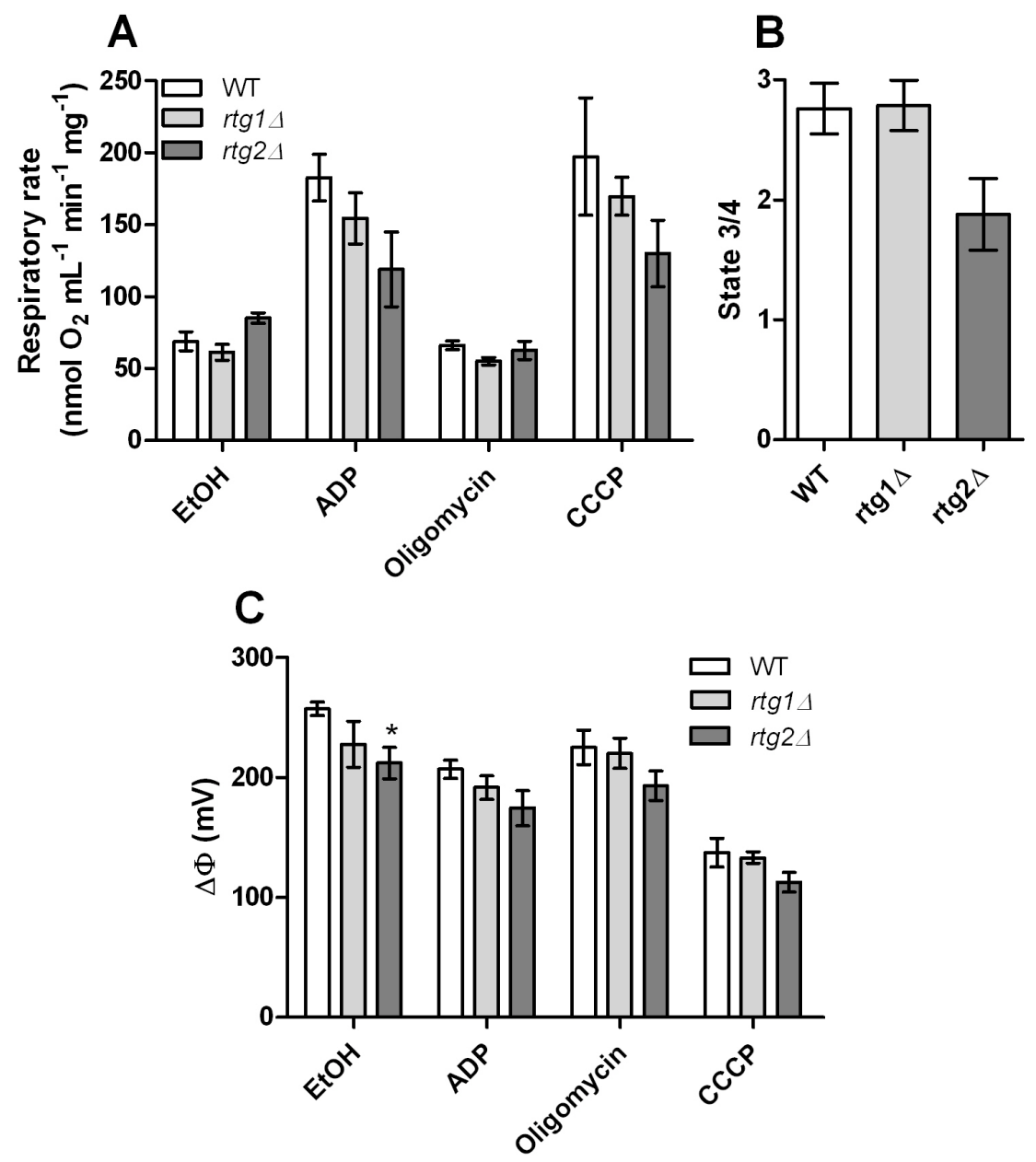

Figure 6. There are no differences in respiratory rates, respiratory control ratios and membrane potentials between mitochondria from WT and $\mathbf{r t g} \Delta$ cells grown for $\mathbf{3}$ days. (A) Respiratory rates of isolated mitochondria extracted from cells grown in YPD for 3 days were determined as described in Materials and Methods. Measurements were conducted in the presence of $1 \%$ ethanol, $0.2 \mu \mathrm{M}$ cytochrome $\mathrm{c}$ and sequential additions of $2 \mathrm{mM}$ ADP, $1.9 \mu \mathrm{M}$ oligomycin and $2.5 \mu \mathrm{M}$ CCCP. The respiratory rate in the presence of $1.8 \mu \mathrm{M}$ antimycin (non-mitochondrial oxygen consumption) was subtracted from all values. (B) Respiratory controls of isolated mitochondria grown for 3 days in YPD medium were calculated as rates in the presence of ethanol and ADP (state 3) divided by rates in the presence of ethanol, ADP and oligomycin (state 4). (C) Membrane potentials in isolated mitochondria extracted from cells grown for 3 days in YPD were determined as described in Materials and Methods. The data represent the averages \pm SEM for 
three independent cultures. Measurements were conducted in the presence of $1 \%$ ethanol, $0.2 \mu \mathrm{M}$ cytochrome $\mathrm{c}$ and sequential additions of $2 \mathrm{mM} \mathrm{ADP}, 1.9 \mu \mathrm{M}$ oligomycin and $3.8 \mu \mathrm{M} \mathrm{CCCP.}{ }^{*} \mathrm{p}<0.05$ compared to WT (t-test).

\subsection{WT mitochondria release higher levels of $\mathrm{H}_{2} \mathrm{O}_{2}$, promoting enhanced stress resistance}

Since we found that the retrograde signaling pathway is involved in reducing mitochondrial activity between 3 and 7 days of growth in fermentative medium (Figure 4), it is possible that RTG-dependent pathway could be targeting damaged mitochondria toward mitophagy, thus maintaining a smaller but healthier mitochondrial pool. Indeed, some authors suggest that one of the main function of mitophagy is to promote mitochondrial quality control by selectively degrading malfunctioning organelles (Lemasters, 2005). In this case, the remaining mitochondria in WT cells would be expected to produce less hydrogen peroxide and other oxidants than those of the $r \operatorname{tg} \Delta$ mutants. In order to assess this directly, we measured hydrogen peroxide release from isolated mitochondria (Figure 7). Surprisingly, we found that WT mitochondria release higher rates of $\mathrm{H}_{2} \mathrm{O}_{2}$ than $r t g \Delta$ mitochondria, when grown for either 3 or 7 days, thus disproving the initial idea that the retrograde pathway regulates the removal of highly oxidizing mitochondria. 

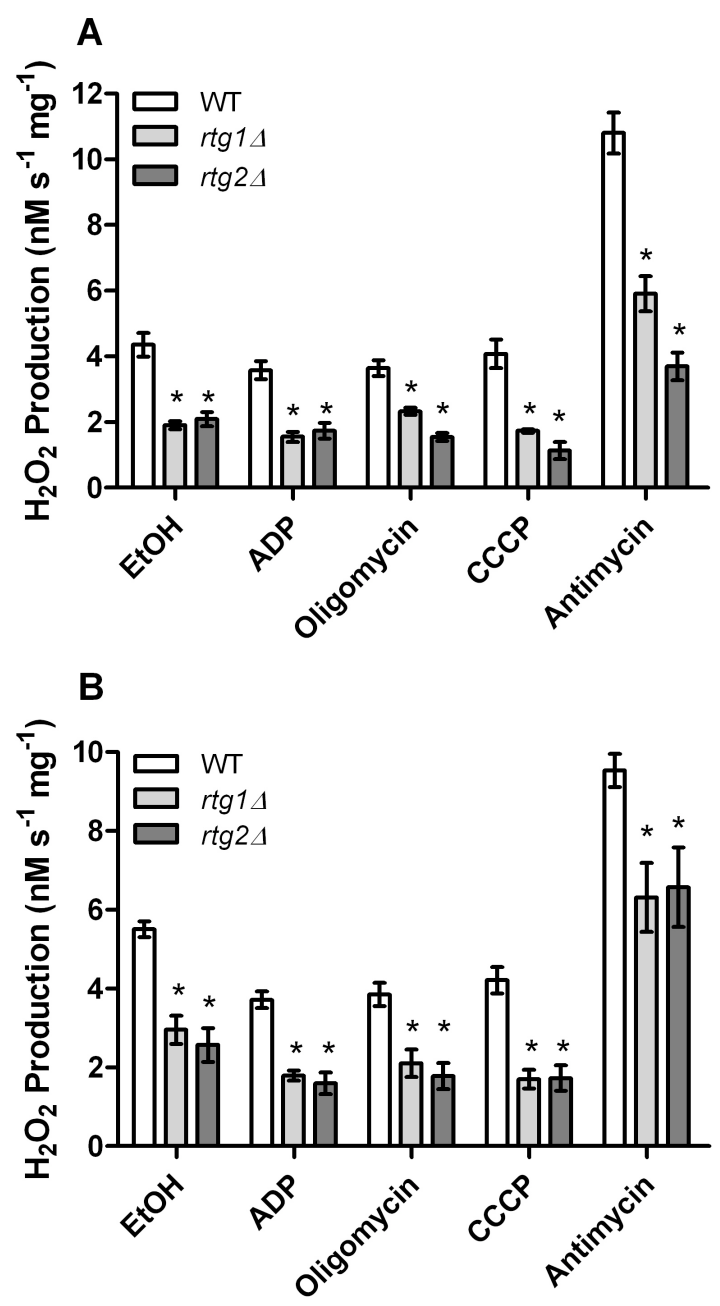

Figure 7. Isolated mitochondria from WT cells produce more $\mathrm{H}_{2} \mathrm{O}_{2}$ than those from $\mathrm{rtg} \Delta$ cells. Hydrogen peroxide production of isolated mitochondria of cells grown in YPD for (A) 3 days and (B) 7 days in the presence of $1 \%$ ethanol, $0.2 \mu \mathrm{M}$ cytochrome c, and sequential additions of $2.5 \mathrm{mM}$ ADP, $1.9 \mu \mathrm{M}$ oligomycin, $3.8 \mu \mathrm{M}$ CCCP and 1.8 $\mu \mathrm{M}$ antimycin was measured as described in Materials and Methods. Calibration was conducted using known concentrations of $\mathrm{H}_{2} \mathrm{O}_{2}$. The data represent the averages \pm SEM for three independent cultures. ${ }^{*} \mathrm{p}<0.05$, compared to WT (t-test).

We were intrigued by the fact that the RTG signaling system was responsible for maintaining a pool of mitochondria that after 7 days of growth is both smaller and produces more oxidants. While mitochondrial oxidants are usually associated with damaging effects, recent attention has been brought to specific conditions in which these oxidants can act as signaling molecules (Barja, 1993; Rhee et al., 2003; Guzy, et al., 2005; Tapia, 2006), usually regulating redox-related processes. Thus, we sought to investigate if the RTG pathway had a role in redox signaling. We investigated first whether $r \operatorname{tg} \Delta$ cells 
had differences in hydrogen peroxide removal capacity (Figure 8). Panel A shows that $r \operatorname{tg} 1 \Delta$ and $r \operatorname{tg} 2 \Delta$ cells present decreases in overall hydrogen peroxide removal ability, which is consistent with the fact that $r \operatorname{tg} 1 \Delta$ present lower catalase and glutathione peroxidase activity than WT (Panel B and C). $r$ tg2 $\Delta$ cells have similar catalase activity when compared to WT cells, but they present much lower glutathione peroxidase activity, thus explaining why their hydrogen peroxide removal capacity stands between that of WT and $r \operatorname{rg} 1 \Delta$ cells.
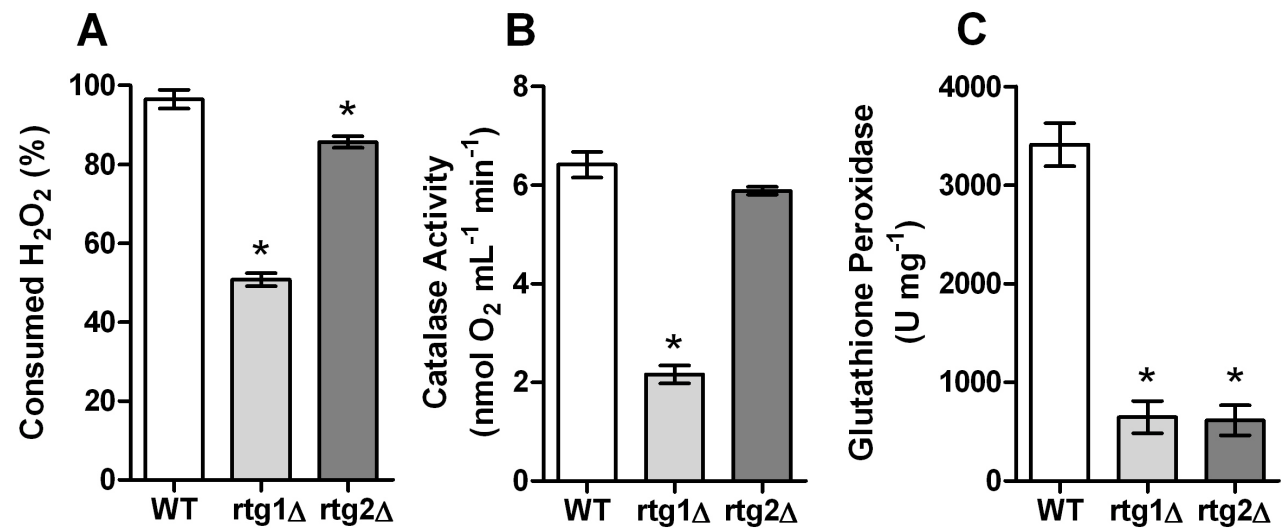

Figure 8. $r$ tg $\Delta$ cells have lower hydrogen peroxide removal capacity and lower catalase and glutathione peroxidase activity. (A) Peroxide removal, (B) Catalase and (C) Glutathione peroxidase activities were measured as described in Materials and Methods. The data represent the averages \pm SEM for four independent cultures. * $<<0.05$ compared to WT (t-test).

In order to verify whether this impaired $\mathrm{H}_{2} \mathrm{O}_{2}$ removal had an impact on cell survival, intact cells were incubated with $\mathrm{H}_{2} \mathrm{O}_{2}$, and their survival relative to controls (no $\mathrm{H}_{2} \mathrm{O}_{2}$ ) was evaluated. Figure 9 shows that $r \operatorname{tg} \Delta$ cells were significantly more sensitive to $\mathrm{H}_{2} \mathrm{O}_{2}$ than WT cells. Overall, these results confirm that retrograde signaling promotes higher stress resistance against external hydrogen peroxide through a hormetic process (Cypser and Johnson, 2002) in which chronically higher mitochondrial oxidant release 
increases antioxidant defenses and protects against acute oxidative stress (Hoffmann et al., 2013; Semchyshyn, 2014).

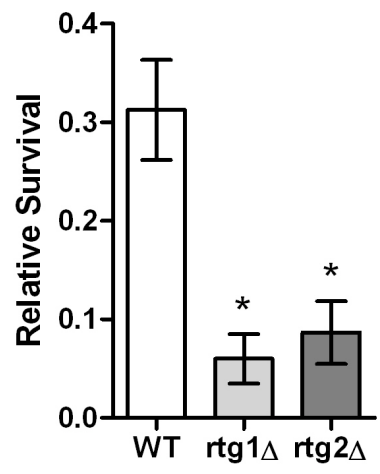

Figure 9. $r$ tg $\Delta$ present lower resistance against hydrogen peroxide than WT cells. Viability of WT, $r \operatorname{tg} 1 \Delta$ or $r \operatorname{tg} 2 \Delta$ strains grown for 7 days in YPD, then incubated in distilled water or $8 \mathrm{mM} \mathrm{H}_{2} \mathrm{O}_{2}$ for 3 hours and plated for 2 days on solid YPD (100 cells per plate). The number of colonies was counted and plotted, normalized to colonies of cells grown in water. The data represent the averages \pm SEM for three independent cultures. ${ }^{*} \mathrm{p}<0.05$, compared to WT ( $\mathrm{t}$ test). 


\section{Discussion}

Although the molecular mechanism of mitochondrial retrograde signaling that occurs in Saccharomyces cerevisiae is well characterized, its impact on mitochondrial activity was not investigated to date. Data available in the literature show that the pathway is involved in allowing the production of intermediary metabolites for biosynthesis, response to low substrate or non-preferable substrate availability (Liao and Butow, 1993; Jia et al., 1997), maintenance of viability (Laio et al., 1991; Matsuura and Anraku, 1993; Conrad-Webb and Butow, 1995; Kirchman et al., 1999; Bourghouts et al., 2004; Journo et al., 2009), as well as communication to other signaling pathways (Komeili et al., 2000; Liu et al, 2001; Giannattasio et al., 2005; Journo et al., 2009; Kawai et al., 2011; Ruiz-Roig et al., 2012). Most of these previous studies focused on genetic approaches and protein interaction analysis. They provided us with the crucial knowledge of the signals involved and their genetic targets. However, how retrograde signaling affects mitochondrial function in a metabolic point of view was a question still unanswered. To gain information on the metabolic impact of retrograde signaling, we subjected null mutants for $R T G 1$ or $R T G 2$ to an array of functional assays aimed at understanding the impact of this pathway on mitochondrial physiology.

The first characteristic we noted was that, when cells are grown in fermentative medium, the lack of retrograde signaling does not affect respiratory metabolism in the early culture hours, but significantly prevents the loss of oxygen consumption which occurs as external substrates are exhausted, between 3 and 7 days (Figure 4, Tahara et al., 2013). The higher respiratory rates observed in $r \operatorname{tg} \Delta$ mutants were mirrored by higher citrate synthase activity, which indicates that overall mitochondrial content was also augmented (Holloszy et al., 1970). The reason why cells defective in RTG-dependent 
retrograde signaling are unable to regulate mitochondrial activity after the exhaustion of oxidizable substrates remains unclear, but may be related to impaired mitophagy in cells deprived of RTG-dependent retrograde signaling (Journo et al., 2009).

Mitophagy is a selective type of autophagy that mediates removal of mitochondria (Lemasters, 2005). While autophagy removes cellular components nonspecifically in response to nutrient deprivation, supplying the cell with energy and molecules essential for biosynthesis until external substrate sources are reestablished (Kuma et al., 2004; Onodera and Ohsumi, 2005), mitophagy targets mitochondria specifically in order to match mitochondrial activity to metabolic demand, removing superfluous organelles during nitrogen-starvation ( $\mathrm{N}$-starvation) in fermentative media (Kissova et al., 2004; Kanki and Klionsky, 2008, Kanki et al., 2009), and guarantees mitochondrial quality by degrading dysfunctional mitochondria (Priault et al., 2005; Nowikovsky et al., 2007), for example during stationary phase of cells grown in lactate (Tal et al., 2007).

If cells defective in retrograde signaling indeed present higher mitochondrial activity due to impaired mitophagy, then RTG mediates selective mitophagy: remaining mitochondria in WT cells become functionally different from those in $r t g \Delta$ mutants after substrate shift (between 3 and 7 days), and present less maximal electron transport activity relative to protein content (Figure 5), with conserved coupling and membrane potentials. Together, these results indicate that the RTG pathway, while decreasing total mitochondrial content during nutrient deprivation, also specifically targets the removal of electron transport chain components. This is, to our knowledge, the first time that the RTG pathway was shown to be involved in the physiological reduction of mitochondrial activity in response to a substrate shift. When cells are grown in respiratory medium, no differences in mitochondrial activity (oxygen consumption of intact cells) and in 
mitochondrial mass (citrate synthase activity) are observed between WT cells and cells lacking retrograde signaling. These results agree with the fact that mitophagy is inhibited when cells are grown in respiratory medium, even when shifted to $\mathrm{N}$ starvation medium, since mitochondria are required to use the available carbon source (Kanki and Klionsky, 2008), and further highlight the importance of the retrograde signaling pathway in adapting the cell to the substrate shift that takes place when it is grown in fermentative medium.

Interestingly, the RTG-dependent decrease in respiratory activity in fermentative medium in response to substrate deprivation is not related to a lower release of hydrogen peroxide from mitochondria (Figure 6). On the contrary, mitochondria from WT cells release higher amounts of hydrogen peroxide than mitochondria from $r t g \Delta$ mutants. The higher $\mathrm{H}_{2} \mathrm{O}_{2}$ release rates in WT mitochondria are compatible with the lower respiratory rates observed in Figure 5, since lower electron transport activity is often accompanied by higher mitochondrial oxidant production (Turrens, 2003; Tahara et al., 2009; Figueira et al., 2013). However, the enhanced peroxide release in WT mitochondria is observed even in the presence of the respiratory inhibitor antimycin A, and therefore cannot be ascribed to changes in electron transport rates, since the electron transport chain is inhibited under this condition. It is possible that in changing mitochondrial activities by decreasing respiratory capacity relative to the total mitochondrial protein, the RTG pathway promotes a change in the balance between the production of reducing equivalents through the citric acid cycle and electron flow, thus favoring oxidant production by the electron transport chain, or even at the level of mitochondrial flavoenzymes that generate oxidants (Adam-Vizi and Chinopoulos, 2006; Figueira et al., 2013). 
Because the enhanced release of $\mathrm{H}_{2} \mathrm{O}_{2}$ was observed in WT mitochondria under physiologically-relevant conditions and was specifically abrogated by the inhibition of retrograde signaling, we questioned if these oxidants could be mediating redox signaling. Although ROS are often associated with damage to DNA, protein and lipids, causing pathologies resulting from oxidative stress (Cross et al., 1987), recently is has become increasingly evident that they also act as signaling molecules regulating physiological processes (Finkel, 2011). Hydrogen peroxide, for instance, regulates protein activity by oxidation of cysteine residues that are converted from thiolate anions (Cys-S-) to the sulfenic form (Cys-SOH), causing allosteric changes in the protein (Finkel, 2012). The sulfenic form can be reduced back to thiolate anions by the dissulfide reductases thioredoxin and glutaredoxin, returning the protein to its original conformation and activity (Winterbourn and Hampton, 2008). However, high levels of $\mathrm{H}_{2} \mathrm{O}_{2}$ (i.e. higher than nanomolar range) oxidize thiolate anions to sulfinic $\left(\mathrm{Cys}-\mathrm{SO}_{2} \mathrm{H}\right)$ or sulfonic $\left(\mathrm{Cys}-\mathrm{SO}_{3} \mathrm{H}\right)$ species, an irreversible modification that permanently damages the protein (Schieber and Chandel, 2014). This is an example of how ROS can act as signaling molecules or as damage sources depending on their concentration.

It is known that not all stressors present a linear relationship between concentration and effect. In many cases, low doses are actually beneficial, inducing a stress response that allows resistance against higher doses, a phenomenon called hormesis (Southam and Ehrlich, 1943; Calabrese et al., 2007). Examples include brief series of hypoxic episodes that reduce damage by subsequent myocardial infarction (Murry et al., 1986), small exposure to mutagens that later on reduces the response to higher concentrations (Samson and Cairns, 1977) and low doses of chemicals, such as carbon tetrachloride, that protect against larger exposure to them (Ugazio et al., 1972). Hormesis also occurs with endogenous agonists, such as the neurotransmitter 
glutamate, that at low levels activate receptors and triggers stress response pathways in neurons that promote their survival, but that at high doses kills nerve cells (Jiang et al., 2005). Mitochondrial oxidants have also shown hormetic responses (Yun and Finkel, 2014). Impairing glucose metabolism in C. elegans by exposure to 2-deoxy-D-glucose (2DG) or restricting glucose availability increases worm life span by increasing mitochondrial respiration and ß-oxidation, which results in increased levels of ROS. A week after 2DG exposure, catalase activity is increased. Treatment with antioxidant $N$ acetylcysteine before or after treatment with 2DG blocks the extension in life span, showing that induced release of ROS activates a hormetic stress response, increasing longevity (Schultz et al., 2007). In S. cerevisiae, it was shown that reduced TOR signaling increases superoxide production and extends chronological life span (CLS), while overexpression of SOD2, encoding manganese superoxide dismutase, a scavenger of superoxide, reduces CLS (Pan et al., 2011). It has also been shown that cytosolic catalase activity in yeast increases with a $\mathrm{H}_{2} \mathrm{O}_{2}$ challenge and promotes higher cell viability (Martins and English, 2014). In mammalian cells, the Bcl-2 family of proteins increase chronic mitochondrial ROS release, resulting in protection against acute oxidative imbalance (Kowaltowski et al., 2004; Kowaltowski and Fiskum, 2005; Krishna et al., 2011).

The retrograde signaling pathway could be acting in a similar way as these examples, promoting a hormetic response to increased endogenous $\mathrm{H}_{2} \mathrm{O}_{2}$ production. In fact, we found that $r \operatorname{tg} \Delta$ mutants present impaired $\mathrm{H}_{2} \mathrm{O}_{2}$ removal capabilities (Figure 8) and are significantly more succeptible to oxidative stress (Figure 9), showing that the RTG-dependent retrograde signaling pathway promotes an elevated $\mathrm{H}_{2} \mathrm{O}_{2}$ release that induces an increase in the activity of antioxidant ezymes and results in higher resistance to oxidative stress. This involvement of the RTG pathway in redox resistance is, to our 
knowledge, yet undescribed, and mirrors the effect of other pathways that control mitochondrial function and redox balance coordinately, including PGC-1 family coactivators (Jones et al., 2012; Lin et al., 2005). 


\section{Conclusion}

Altogether, the results presented in this work indicate that RTG-dependent retrograde mitochondria-to-nucleus signaling modulates not only mitochondrial mass in response to substrate changes, but also mitochondrial activity, resulting in hormetic induction of antioxidant defenses and increased stress resistance. These results highlight once again the importance of coordinated responses maintaining oxidative energy metabolism and redox balance in eukaryotic cells. 


\section{References}

Adam-Vizi, V, Chinopoulos, C (2006) Bioenergetics and the formation of mitochondrial reactive oxygen species. Trends Pharmacol Sci, 27, 639-45.

Akerman, KE, \& Wikström, MK (1976) Safranine as a probe of the mitochondrial membrane potential. FEBS Lett, 68, 191-7.

Amuthan, G, Biswas, G, Anandatheerthavarda, HK, Vijayasarathy, C, Shephard, HM, Avadhani, NG (2002) Mitochondrial stress-induced calcium signaling, phenotypic changes and invasive behavior in human lung carcinoma A549 cells. Oncogene, 21, 783949.

Arnould, T, Vankoningsloo, S, Renard, P, Houbion, A, Ninane, N, Demazy, C, Remacle, J, Raes, M (2002) CREB activation induced by mitochondrial dysfunction is a new signaling pathway that impairs cell proliferation. EMBO J, 21, 53-63.

Babcock, DF, Herrington, J, Goodwin, PC, Park, YB, Hille, B (1997) Mitochondrial participation in the intracellular $\mathrm{Ca}^{2+}$ network. J Cell Biol, 136, 833-44.

Barja, G (1993) Oxygen radicals, a failure or a success of evolution? Free Radic Res Commun, 18, 63-70.

Biswas, G, Adebanjo, OA, Freedman, BD, Anandatheerthavarda, HK, Vijayasarathy, C, Zaidi, M, Kotlikoff, M, Avadhani, NG (1999) Retrograde $\mathrm{Ca}^{2+}$ signaling in C2C12 skeletal myocytes in response to mitochondrial genetic and metabolic stress: a novel mode of interorganelle crosstalk. EMBO J, 18, 522-33.

Biswas, G, Anandatheerthavarda, HK, Zaidi, M, Avadhani, NG (2003) Mitochondria to nucleus mechanism of NFkappaB/Rel activation through calcineurin-mediated inactivation of IkappaBbeta. J Cell Biol, 161, 507-19.

Bradford, MM (1976) A rapid and sensitive method for the quantitation of microgram quantities of protein utilizing the principle of protein-dye binding. Anal Biochem, 72, 248-54.

Borghouts, C, Benguria, A, Wawryn, J, Jazwinski, SM (2004) Rtg2 protein links metabolism and genome stability in yeast longevity. Genetics, 166, 765-77.

Butow, RA, Avadhani, NG (2004) Mitochondrial signaling: the retrograde response. Mol Cell, 14, 1-15.

Calabrese, EJ, Bachmann, KA, Bailer, AJ, et al. (2007) Biological stress response terminology: Integrating the concepts of adaptative response and preconditioning stress with a hormetic dose-response framework. Toxicol Appl Pharmacol, 222, 122-8.

Cardenas, ME, Cutler, NS, Lorenz, MC, Di Como, CJ, Heitman, J (1999) The TOR signaling cascade regulates gene expression in response to nutrients. Genes Dev, 13, 3271-79.

Cerqueira, FM, Cunha, FM, Laurindo, FR, Kowaltowski, AJ (2012) Calorie restriction increases cerebral mitochondrial respiratory capacity in a NO-mediated mechanism: impact on neuronal survival. Free Radic Biol Med, 52, 1236-41.

Chelstowska, A, Liu, Z, Jia, Y, Amberg, D, Butow, RA (1999) Signalling between mitochondria and the nucleus regulates the expression of a new D-lactate dehydrogenase activity in yeast. Yeast, 15, 1377-91.

Collier, JJ, Doan, TT, Daniels, MC, Schurr, JR, Kolls, JK, Scott, DK (2003) c-Myc is required for the glucose-mediated induction of the metabolic enzyme genes. J Biol Chem, 278,6588-95.

Conrad-Webb, H, Butow, RA (1995) A polymerase switch in the synthesis of rRNA in Saccharomyces cerevisiae. Mol Cell Biol, 15, 2420-8. 
Copeland, JM, Cho, J, Lo, T Jr, Hur, JH, Bahadorani, S, Arabyan, T, Rabie, J, Soh, J, Walker DW (2009) Extension of Drosophila life span by RNAi of the mitochondrial respiratory chain. Curr Biol, 19, 194-99.

Cristina, D, Cary, M, Lunceford, A, Clarke, C, Kenyon, C (2009) A regulated response to impaired respiration slows behavioral rates and increases lifespan in Caenorhabditis elegans. PLOS Genet, 5, 1000450.

Cross, CE, Halliwell, B, Borish, ET, Pryor, WA, Ames, BN, Saul, RL, McCord, JM, Harman, D (1987) Oxygen radicals and human disease. Ann Intern Med, 107, 526-45.

Cypser, JR, Johnson, TE (2002) Multiple stressors in Caenorhabditis elegans induce stress hormesis and extended longevity. J Gerontol A Biol Sci Med Sci, 57, B109-14.

Dai, DF, Chiao, YA, Marcinek, DJ, Szeto, HH, Rabinovitch, PS (2014) Mitochondrial oxidative stress in aging and healthspan. Longev Healthspan, 3, Epub ahead of print.

Dell'agnello, C, Leo, S, Agostino, A, et al. (2007) Increased longevity and refractoriness to $\mathrm{Ca}(2+)$-dependent neurodegeneration in Surf1 knockout mice. Hum Mol Genet, 16, 43144.

Deluca, HF, Engstrom, GW (1961) Calcium uptake by rat kidney mitochondria. Proc Natl Acad Sci U S A, 47, 1744-50.

Dillin, A, Hsu, AL, Arantes-Oliveira, N, Lehrer-Graiwer, J, Hsin, H, Fraser, AG, Kamath, RS, Ahringer, J, Kenyon, C (2002) Rates of behaviour and aging specified by mitochondrial function during development. Science, 298, 2398-401.

Durieux, J, Wolf, S, Dillin, A (2011) The cell-non-autonomous nature of electron transport chain-mediated longevity. Cell, 144, 79-91.

Duyal, MP, Kessler, DJ, Spicer, DB, Sonenshein, GE (1990) Binding of NF-KB-like factors to regulatory sequences of the c-myc gene. Curr Top Microbiol Immunol, 166, 211-220.

Epstein, CB, Waddle, JA, Hale, W 4th, Davé, V, Thornton, J, Macatee, TL, Garner, HR, Butow, RA (2001) Genome-wide responses to mitochondrial dysfunction. Mol Biol Cell, 12, 297-308.

Ferranti, R, da Silva, MM, Kowaltowski, AJ (2003) Mitochondrial ATP-sensitive K+ channel opening decreases reactive oxygen species generation. FEBS Lett, 536, 51-5.

Figueira, TR, Barros, MH, Camargo, AA, Castilho, RF, Ferreira, JC, Kowaltwoski, AJ, Sluse, FE, Souza-Pinto, NC, Vercesi, AE (2013) Antioxid Redox Signal, 18, 2019-74.

Finkel, T (2011) Signal transduction by reactive oxygen species. J Cell Biol, 194, 7-15.

Finkel, T (2012) From sulfenylation to sulfhydration: what a thiolate needs to tolerate. Sci Signal, 5, pe10.

Forsberg, H, Gilstring, CF, Zargari, A, Martínez, P, Ljungdahl, PO (2001) The role of the yeast plasma membrane SPS nutrient sensor in the metabolic response to extracellular amino acids. Mol Microbiol, 42, 215-28.

Giannattasio, S, Liu, Z, Thornton, J, Butow, RA (2005) Retrograde response to mitochondrial dysfunction is separable from TOR1/2 regulation of retrograde gene expression. J Biol Chem, 280, 42528-35.

Guzy, RD, Hoyos, B, Robin, E, Chen, H, Liu, L, Mansfield, KD, Simon, MC, Hammerling, U, Schumacker, PT (2005) Mitochondrial complex III is required for hypoxia-induced ROS production and cellular oxygen sensing. Cell Metab, 1, 401-8.

Hardwick, JS, Kuruvilla, FG, Tong, JK, Shamji, AF, Schreiber, SL (1999) Rapamycinmodulated transcription defines the subset of nutrient-sensitive signaling pathways directly controlled by the Tor proteins. Proc Natl Acad Sci USA, 96, 14866-70.

Hockenbery, D, Nuñez, G, Milliman, C, Schreiber, RD, Korsmeyer, SJ (1990) Bcl-2 is an inner mitochondrial membrane protein that blocks programmed cell death. Nature, 348, 334-6. 
Hoffmann, GR, Moczula, AV, Laterza, AM, Macneil, LK, Tartaglione, JP (2013) Adaptive response to hydrogen peroxide in yeast: induction, time course, and relationship to dose-response models. Environ Mol Mutagen, 54, 384-96.

Holloszy, JO, Oscai, LB, Don, IJ, Molé, PA (1970) Mitochondrial citric acid cycle and related enzymes: adaptative response to exercise. Biochem Biophys Res Commmun, 40, 1368-73.

Hütter, E, Unterluggauer, H, Garedew, A, Jansen-Dürr, P, Gnaiger, E (2006) Highresolution respirometry - a modern tool in aging research. Exp Gerontol, 41, 103-9.

Ichas, S, Jouaville, LS, Mazat, JP (1997) Mitochondria are excitable organelles capable of generating and conveying electrical and calcium signals. Cell, 89, 1145-53.

Jia, Y, Rothermel, B, Thornton, J, Butow, RA (1997) A basic helix-loop-helix-leucine zipper transcription complex in yeast functions in a signaling pathway from mitochondria to the nucleus. Mol Cell Biol, 17, 1110-7.

Jazwinski, SM (2000) Metabolic control and gene dysregulation in yeast aging. Ann NY Acad Sci, 908, 21-30.

Jazwinski, SM (2012) The retrograde response: when mitochondrial quality control is not enough. Biochim Biophys Acta, 1833, 400-9.

Jazwinski, SM (2014) The retrograde response: a conserved compensatory reaction to damage from within and from without. Prog Mol Biol Transl Sci, 127, 133-54.

Jiang, X, Tian, F, Mearow, K, Okagaki, P, Lipsky, RH, Marini, AM (2005) The excitoprotective effect of $N$-methyl-D-aspartate receptors is mediated by brain-delivered neurotrophic factor autocrine loop in cultures hippocampal neurons. J Neurochem, 94, 713-22.

Jones, AW, Yao, Z, Vicencio, JM, Karkucinska-Wieckowska, A, Szabadkai, G (2012) PGC-1 family coactivators and cell fate: roles in cancer, neurodegeneration, cardiovascular disease and retrograde mitochondria-nucleus signalling. Mitochondrion, 12, 86-99.

Journo, D, Mor, A, Abeliovich, H (2009) Aup1-mediated regulation of Rtg3 during mitophagy. J Biol Chem, 284, 35885-95.

Kamat, PK, Kalani, A, Kyles, P, Tyagi, SC, Tyagi, N (2014) Autophagy of mitochondria: a promising therapeutic target for neurodegenerative disease. Cell Biochem Biophys, Epub ahead of print.

Kanki, T, Klionsky, DJ (2008) Mitophagy in yeast occurs through a selective mechanism. J Biol Chem, 283, 32386-93.

Kanki, T, Wang, K, Baba, M, Bartholomew, CR, Lynch-Day, MA, Du, Z, Geng, J, Mao, K, Yang, Z, Yen, WL, Klionsky, DJ (2009) A genomic screen for yeast mutants defective in selective mitochondria autophagy. Mol Biol Cell, 20, 4730-8.

Kawai, S, Urban, J, Piccolis, M, Panchaud, N, De Virgilio, C, Loewith, R (2011) Mitochondrial genomic dysfunction causes dephosphorylation of Sch9 in the yeast Saccharomyces cerevisiae. Eukaryot Cell, 10, 1367-9.

Kim, I, Rodriguez-Enriquez, S, Lemasters, JJ (2007) Selective degradation of mitochondria by mitophagy. Arch Biochem Biophys, 462, 245-53.

Kirchman, PA, Kim, S, Lai, CY, Jazwinski, SM (1999) Interorganelle signaling is a determinant of longevity in Saccharomyces cerevisiae. Genetics, 152, 179-90.

Kissova, I, Deffieu, M, Manon, S, Camougrand, N (2004) Uth1p is involved in the autophagic degradation of mitochondria.J Biol Chem, 279, 39068-74.

Kissova, I, Salin, B, Schaeffer, J, Bhatia, S, Manon, S, Camougrand, N (2007) Selective and non-selective autophagic degradation of mitochondria in yeast. Autophagy, 3, 329-36. 
Komeili, A, Wedaman, KP, O'Shea, EK, Powers, T (2000) Mechanism of metabolic control. Target of rapamycin signaling links nitrogen quality to the activity of the Rtg1 and Rtg3 transcription factors. J Cell Biol, 151, 863-78.

Kowaltowski, AJ, Cosso, RG, Campos, CB, Fiskum, G (2002) Effect of Bcl-2 overexpression on mitochondrial structure and function. J Biol Chem, 277, 42802-7.

Kowaltowski, AJ, Fenton, RG, Fiskum, G (2004) Bcl-2 family proteins regulate mitochondrial reactive oxygen production and protect against oxidative stress. Free Radic Biol Med, 37, 1845-53.

Kowaltowski, AJ, Fiskum, G (2005) Redox mechanisms of cytoprotection by Bcl-2. Antioxid Redox Signal, 7, 508-14.

Krishna, S, Low, IC, Pervaiz, S (2011) Regulation of mitochondrial metabolism: yet another facet in the biology of the oncoprotein Bcl-2. Biochem J, 435, 545-51.

Kroemer, G, Galluzzi, L, Brenner, C (2007) Mitochondrial membrane permeabilization in cell death. Physiol Rev, 87, 99-163.

Kuma, A, Hatano, M, Matsui, M, Yamamoto, A, Nakaya, H, Yoshimori, T, Ohsumi, Y, Tokuhisa, T, Mizushima, N (2004) The role of autophagy during the early neonatal starvation period. Nature, 432, 1032-6.

Lapoite, J, Hekimi, S (2008) Early mitochondrial dysfunction in long-lived Mclk1 +/mice. J Biol Chem, 283, 26217-27.

Lee, SS, Lee, RY, Fraser, AG, Kamath, RS, Ahringer, J, Ruvkun, G (2003) A systematic RNAi screen identifies a critical role for mitochondria in C. elegans longevity. Nat Genet, 33, 40-8.

Lee, SJ, Hwang, AB, Kenyon, C (2010) Inhibition of respiration extends C. elegans life span via reactive oxygen species that increase HIF-1 activity. Curr Biol, 20, 2131-6.

Lemasters, JJ (2005) Selective mitochondrial autophagy, or mitophagy, as a targeted defense against oxidative stress, mitochondrial dysfunction, and aging. Rejuvenation Res, 8, 3-5.

Liao, XS, Small, WC, Crere, PA, Butow, RA (1991) Intramitochondrial functions regulate nonmitochondrial citrate synthase (CIT2) expression in Saccharomyces cerevisiae. Mol Cell Biol, 11, 38-46.

Liao, X, Butow, RA (1993) RTG1 and RTG2: two yeast genes required for a novel path of communication from mitochondria to the nucleus. Cell, 72, 61-71.

Lin, J, Handschin, C, Spiegelman, BM (2005) Metabolic control through the PGC-1 family of transcription coactivators. Cell Metab, 1, 361-70.

Liu, Z, Butow, RA (1999) A transcriptional switch in the expression of yeast tricarboxylic acid cycle genes in response to a reduction or loss of respiratory function. Mol Cell Biol, $19,6720-8$.

Liu, Z, Sekito, T, Epstein, CB, Butow, RA (2001) RTG-dependent mitochondria to nucleus signaling is negatively regulated by the seven WD-repeat protein Lst8p. EMBO J, 20, 7209-19.

Liu, Z, Sekito, T, Spírek, M, Thornton, J, Butow, RA (2003) Retrograde signaling is regulated by the dynamic interaction between Rtg2p and Mks1p. Mol Cell, 12, 401-11.

Liu, Z, Spírek, M, Thornton, J, Butow, RA (2005) A novel degron-mediated degradation of the RTG pathway regulator, Mks1p, by SCFGrr1. Mol Biol Cell, 16, 4893-904.

Liu, Z, Butow, RA (2006) Mitochondrial retrograde signaling. Annu rev Genet, 40, 159-85. Liu, J, Wu, Q, He, D, Ma, T, Du, L, Dui, W, Guo, X, Jiao, R (2011) Drosophila sbo regulates lifespan through its function in the synthesis of coenzyme Q in vivo. J Genet Genomic, 38, 225-34. 
Lu, ZY, Yu, SP, Wei, JF, Wei, L (2006) Age-related neural degeneration in nuclear-factor kappaB p50 knockout mice. Neuroscience, 139, 965-78.

Luo, Y, Bond, JD, Ingram, VM (1997) Compromised mitochondrial function leads to increased cytosolic calcium and to activation of MAP kinases. Porc Natl Acad Sci USA, 94, 9705-10.

Mallilankaraman, K, Doonan, P, Cárdenas, C, Chandramoorthy, HC, Müller, M, Miller, R, Hoffman, NE, Gandhirajan, RK, Molgó, J, Birnbaum, MJ, Rothberg, BS, Mak, DO, Foskett, JK, Madesh, M (2012) MICU1 is an essential gatekeeper for MCU-mediated mitochondrial $\mathrm{Ca}^{2+}$ uptake that regulates cell survival. Cell, 151, 630-44(a).

Mallilankaraman, M., Cárdenas, C., Doonan, P. J., Chandramoorthy, H. C., Irrinki, K. M., Golenár, T., Csordás, G, Madireddi, P, Yang, J, Müller, M, Miller, R, Kolesar, JE, Mogó, J, Kaufman, B, Hajnóczky, G, Foskett, JK, Madesh, M (2012) MCUR1 is an essential component of mitochondrial $\mathrm{Ca}^{2+}$ uptake that regulates cellular metabolism. Nat Cell Biol, 12, 1336-43(b).

Martins, D, English, AM (2014) Catalase activity is stimulated by $\mathrm{H}_{2} \mathrm{O}_{2}$ in rich culture medium and is required for $\mathrm{H}_{2} \mathrm{O}_{2}$ resistance and adaptation in yeast. Redox Biol, $2 i$ 30813.

Marusisch, MF, Robinson, BH, Taanman, JW, Kim, SJ, Schillace, R, Smith, JL, Capaldi, RA (1997) Expression of mtDNA and nDNA encoded respiratory chain proteins in chemically and genetically-derived Rho0 human fibroblasts: a comparison of subunit proteins in normal fibroblasts treated with ethidium bromide and fibroblasts from a patient with mtDNA depletion syndrome. Biochim Biophys Acta, 1362, 145-59.

Matsuura, A, Anraku, Y (1993) Characterization of the MKS1 gene, a new negative regulator of the Ras-cyclic AMP pathway in Saccharomyces cerevisiae. Mol Gen Genet, 238, 6-16.

Miceli, MV, Jazwinski, SM (2005) Common and cell type-specific responses of human cells to mitochondrial dysfunction. Exp Cell Res, 302, 270-80.

Miceli, MV, Jiang, JC, Tiwari, A, Rodriguez-Quiñones, JF, Jazwinski, SM (2012) Loss of mitochondrial membrane potential triggers the retrograde response extending yeast replicative lifespan. Front Genet, 2, 102.

Murry, CE, Jennings, RB, Reimer, KA (1986) Preconditioning with ischemia: a delay of letahl cell injury in ischemic myocardium. Circulation, 74, 1124-36.

Nagatogawa, H, Suzuki, K, Kamada, Y, Ohsumi, Y (2009) Dynamics and diversity in autophagy mechanisms: lessons from yeast. Nat Rev Mol Cell Biol, 10, 458-67.

Nicholls, DG, Ferguson, SJ (2013) Bioenergetics. Amsterdam: Academic Press.

Nowikovsky, K, Reipert, S, Devenish, RJ, Schweyen, RJ (2007) Mdm38 protein depletion causes loss of mitochondrial $\mathrm{K}^{+} / \mathrm{H}^{+}$exchange activity, osmotic swelling and mitophagy. Cell Death Differ, 14, 1647-56.

Onodera, J, Ohsumi, Y. Autophagy is required for maintenance of amino acid levels and protein synthesis under nitrogen starvation. J Biol Chem, 280, 31582-6.

Pan, Y, Schroeder, EA, Ocampo, A, Barrientos, A, Schadel, GS (2011) Regulation of yeast chronological life span by TORC1 via adaptative mitochondrial ROS signaling. Cell Metab, 13, 668-78.

Parikh, VS, Morgan, MM, Scott, R, Clements, LS, Butow, RA (1987) The mitochondrial genotype can influence nuclear gene expression in yeast. Science, 235, 576-80.

Priault, M, Salin, B, Schaeffer, J, Valette, FM, di Rago, JP, Martinou, JC (2005) Impairing the bioenergetic status and the biogenesis of mitochondria triggers mitophagy in yeast. Cell Death Differ, 12, 1613-21. 
Rhee, SG, Chang, TS, Bae, YS, Lee, SR, Kang, SW (2003) Cellular regulation by hydrogen peroxide. J Am Soc Nephrol, 14, S211-15.

Rizzuto, R, Brini, M, Murgia, M, Pozzan, T (1993) Microdomains with high $\mathrm{Ca}^{2+}$ close to IP3-sensitive channels that are sensed by neighbouring mitochondria. Science, 262, 74447.

Rothermel, BA, Thornton, JL, Butow, RA (1997) Rtg3p, a basic helix-loop-helix/leucine zipper protein that functions in mitochondrial-induced changes in gene expression, contains independent activation domains. J Biol Chem, 272, 19801-7.

Ruiz-Roig, C, Noriega, N, Duch, A, Posas, F, de Nadal, E (2012) The Hog1 SAPK controls the Rtg1/3 transcriptional complex activity by multiple regulatory mechanisms. Mol Biol Cell, 23, 4286-96.

Sagan, L (1967) On the origin of mitosing cells. J Theor Biol, 14, 255-74.

Samson, L, Cairns, J (1977) A new pathway for DNA repair in Escherichia coli. Nature, 267, 281-3.

Sancak, Y, Markhard, AL, Kitami, T, Kovács-Bogdán, E, Kamer, KJ, Udeshi, ND, Carr, SA, Chaudhuri, D, Clapham, DE, Li, AA, Calvo, SE, Goldberger, O, Mootha, VK (2013) EMRE is an essential component of the mitochondrial calcium uniporter complex. Science, 342, 1379-82.

Schiebel, M, Chandel, NS (2014) ROS function in redox signaling and oxidative stress. Curr Biol, 24, R453-62.

Schultz, TJ, Zarse, K, Voigt, A, Urban, N, Birringer, M, Ristow, M (2007) Glucose restriction extends Caenorhabditis elegans life span by inducing mitochondrial respiration and increasing oxidative stress. Cell Metab, 6, 280-93.

Semchyshyn, HM (2014) Hormetic concentrations of hydrogen peroxide but not ethanol induce cross-adaptation to different stresses in budding yeast. Int J Microbiol, Epub ahead of print.

Sekito, T, Thornton, J, Butow, RA (2000) Mitochondria-to-nuclear signaling is regulated by the subcellular localization of the transcription factors Rtg1p and Rtg3p. Mol Biol Cell, 11, 2103-15.

Sekito, T, Thornton, J, Butow, RA (2002) RTG-dependent mitochondria-to-nucleus signaling is regulated by MKS1 and is linked to the formation of yeast prion [URE3]. Mol Biol Cell, 13, 795-804.

Sinclair, DA, Guarente, L (1997) Extrachromosomal rDNA circles - a cause of aging in yeast. Cell, 91, 1033-42.

Southam, CM, Ehrlich, J (1943) Effects of extracts of western red cedar heartwood on certain wood-decaying fungi in culture. Phytopathology, 33, 517-24.

Srere, PA (1969) Citrate synthase. Methods Enzymol, 13, 3-11.

Srinivasan V, Kriete, A, Sacan, A, Jazwinski, SM (2010) Comparing the yeast retrograde response and NF-kappaB stress responses: implications for aging. Aging Cell, 9, 933-41.

Sun J, Kale, SP, Childress, AM, Pinswasdi, C, Jazwinski, SM (1994) Divergent roles of RAS1 and RAS2 in yeast longevity. J Biol Chem, 269, 18638-45.

Tahara, EB, Navarete, FD, Kowaltowski, AJ (2009). Tissue-, substrate-, and site-specific characteristics of mitochondrial reactive oxygen species generation. Free Radic Biol Med, 46, 1283-97.

Tahara, EB, Cunha, FM, Basso, TO, Della Bianca, BE, Gombert, AK, Kowaltowski, AJ (2013) Calorie restriction hysteretically primes aging Saccharomyces cerevisiae toward more effective oxidative metabolism. PLoS One, 8, doi: 10.1371. 
Tal, R, Winter, G, Ecker, N, Klionsky, DJ, Abeliovich, H (2007) Aup1p, a yeast mitochondrial protein phosphatase homolog, is required for efficient stationary phase mitophagy and cell survival. J Biol Chem, 282, 5617-24.

Tapia, PC (2006) Sublethal mitochondrial stress with an attendant stoichiometric augmentation of reactive oxygen species may precipitate many of the beneficial alterations in cellular physiology produced by caloric restriction, intermittent fasting, exercise and dietary phytonutrients: "Mitohormesis" for health and vitality. Med Hypotheses, 66, 832-43.

Traven, A, Wong, JM, Xu, D, Sopta, M, Ingles, CJ (2001) Interorganellar communication. Altered nuclear gene expression profiles in a yeast mitochondrial DNA mutant. $J$ Biol Chem, 276, 4020-7.

Turrens, JF (2003) Mitochondrial formation of reactive oxygen species. J Physiol, 552, 335-44.

Ugazio, G, Koch, RR, Recknagel, RO (1972) Mechanism of protection against carbon tetrachloride by prior carbon tetrachloride administration. Exp Mol Pathol, 16, 281-5.

Urban, J, Soulard, A, Huber, A, Lippman, S, Mukhopadhyay, D, Deloche, O, Wanke, V, Anrather, D, Ammerer, G, Riezman, H, Broach, JR, De Virgilio, C, Hall, MN, Loewith, R (2007) Sch9 is a major target of TORC1 in Saccharomyces cerevisiae. Mol Cell, 26, 663-74.

Vanden Berghe, W, Ndlovu, MN, Hoya-Arias, R, Dijsselbloem, N, Gerlo, S, Haegman, G (2006) Keeping up NF-happaB appearences: epigenetic control of immunity or inflammation-triggered epigenetics. Biochim Pharmacol, 72, 1114-31.

Vanfleteren, JR, De Vreese, A (1995) The gerontogenes age-1 and daf-2 determine metabolic rate potential in aging Caenorhabditis elegans. FASEB J, 9, 1355-61.

Vasington, FD, Murphy, JV (1962). Ca ion uptake by rat kidney mitochondria and its dependence on respiration and phosphorylation. J Biol Chem, 237, 2670-7.

Vélot, C, Haviernik, P, Lauquin, GJ (1996) The Saccharomyces cerevisiae RTG2 gene is a regulator of aconitase expression under catabolite repression conditions. Genetics, 144, 893-903.

Walter, L, Baruah, A, Chang, HW, Pace, HM, Lee, SS (2011) The homeobox protein CEH23 mediated prolonged longevity in response to impaired mitochondrial electron transport chain in C. elegans. PLoS Biol, 9, 1001084.

Wang, H, Morais, R (1997) Up-regulation of nuclear genes in response to ihnibition of mitochondrial DNA expression in chicken cells. Biochim Biophys Acta, 1352, 325-34.

Winterbourn, CC, Hampton, MB (2008) Thiol chemistry and specificity in redox signaling. Free Radic Biol Med, 45, 549-61.

Yang, J, Liu, X, Bhalla, K, Kim, CN, Ibrado, AM, Cai, J, Peng, TI, Jones, DP, Wang, X (1997) Prevention of apoptosis by Bcl-2: release of cytochrome c from mitochondria blocked. Science, 275, 1129-32.

Yang, W, Hekimi, S (2010) Two modes of mitochondrial dysfunction lead independently to lifespan extension in Caenorhabditis elegans. Aging Cell, 9, 433-47.

Yun, J, Finkel, T (2014) Mitohormesis. Cell Metab, 19, 757-66.

Zhang, F, Pracheil, T, Thornton, J, Liu, Z (2013) Adenosine triphosphate (ATP) is a candidate signaling molecule in the mitochondria-to-nucleus retrograde response pathway. Genes (Basel), 4, 86-100.

Zhao, Q, Wang, J, Levichkin, IV, Stasinopoulos, S, Ryan, MT, Hoogenraad, NJ (2002) A mitochondrial specific stress response in mammalian cells. EMBO J, 21, 4411-19.

Zinser, E, Daum, G (1995) Isolation and biochemical characterization of organelles from the yeast, Saccharomyces cerevisiae. Yeast, 11, 493-536. 


\section{Attachments}

\section{Súmula Curricular}

DADOS PESSOAIS

Nicole Quesada Torelli

Nascida em São Paulo em 25 de abril de 1988

EDUCAÇÃO

Nível básico

Colégio Humboldt

São Paulo, Brasil

$1993-2005$

Humboldt Gymnasium

Berlim, Alemanha

Agosto - Dezembro 2004

Nível superior

Universidade de São Paulo

Bacharelado e Licenciatura em Química

2007 - 2011

OCUPAÇÃO

Mestrado 2012 - 2014

Bolsista de Mestrado, CNPq, Agosto 2012 - Julho 2014

Laboratório de Metabolismo Energético

Departamento de Bioquímica

Instituto de Química

Universidade de São Paulo

Químico Agosto - Dezembro 2011

Laboratório de Desenvolvimento de Processos

BASF

Iniciação Científica 2008 - 2010

Bolsista de Iniciação Científica, CNPq, Agosto 2009 - Julho 2010

Laboratório de Bioluminescência de Fungos

Departamento de Química

Instituto de Química

Universidade de São Paulo

PUBLICAÇÕES

Resumos em Congressos

Torelli NQ, da Cunha FM, Kowaltowski AJ. RTG-dependent retrograde signaling controls mitochondrial activity and stress resistance in $S$. cerevisiae. Society for Free Radical Biology and Medicine's Annual Meeting (SFRBM), 2014, Seattle, USA. 
Torelli NQ, da Cunha FM, Kowaltowski AJ. VII Mitomeeting. RTG-dependent retrograde signaling in S. cerevisiae controls mitochondrial and redox status, 2014, Guapé, Brasil.

Torelli NQ, da Cunha FM, Kowaltowski AJ. XLIII Annual Meeting of the Brazilian Society for Biochemistry and Molecular Biology (SBBq). Study of the role of RTG-dependent retrograde signaling pathway in mitochondrial activity maintenance of $S$. cerevisiae, 2014, Foz do Iguaçu, Brasil.

Torelli NQ, da Cunha FM, Kowaltowski AJ. Antioxidants and Redox Process in Health Bilateral Meeting Brazil-Japan. Study of the role of RTG-dependent retrograde signaling pathway in mitochondrial activity maintenance of S. cerevisiae, 2013, São Paulo, Brasil.

Torelli NQ, da Cunha FM, Kowaltowski AJ. 18º Simpósio Internacional de Iniciação Científica. Estudo QSTR de fenóis com fungo bioluminescente, 2010, São Paulo, Brasil.

\section{Artigo Submetido}

Torelli, NQ, Ferreira-Junior, JR, Kowaltowski, AJ, da Cunha, FM. RTG-dependent retrograde signaling controls mitochondrial activity and stress resistance in $S$. cerevisiae. Submetido a Free Radical Biology \& Medicine, Setembro 2014. 

